\title{
An ecosystem-based approach to assess the status of Mediterranean algae-dominated shallow rocky reefs
}

\author{
Thierry Thibaut ${ }^{\mathrm{a}, *}$, Aurélie Blanfuné ${ }^{\mathrm{a}}$, Charles F. Boudouresque a , Sébastien Personnic a , Sandrine Ruitton ${ }^{\mathrm{a}}$, \\ Enric Ballesteros ${ }^{\mathrm{b}}$, Denise Bellan-Santini ${ }^{\mathrm{c}}$, Carlo Nike Bianchi ${ }^{\mathrm{d}}$, Simona Bussotti ${ }^{\mathrm{e}}$, Emma Cebrian ${ }^{\mathrm{b}}$, \\ Adrien Cheminée ${ }^{\text {a,f }}$, Jean-Michel Culioli ${ }^{\mathrm{g}}$, Sandrine Derrien-Courtel ${ }^{\mathrm{h}}$, Paolo Guidetti ${ }^{\mathrm{e}}$, \\ Mireille Harmelin-Vivien ${ }^{\mathrm{a}}$, Bernat Hereu ${ }^{\mathrm{i}}$, Carla Morri ${ }^{\mathrm{d}}$, Jean-Christophe Poggiale ${ }^{\mathrm{a}}$, Marc Verlaque ${ }^{\mathrm{a}}$ \\ a Aix-Marseille University, Mediterranean Institute of Oceanography (MIO), CNRS/INSU, IRD, UM 110, Campus universitaire de Luminy, case 901, 13288 Marseille cedex 09, France \\ b Centre d'Estudis Avançats de Blanes - CSIC, 17300 Blanes, Spain \\ c Aix-Marseille University, Institut Méditerranéen de Biodiversité et d'Ecologie (IMBE), UMR 7263, Station Marine d'Endoume, rue de la batterie des lions, 13007 Marseille, France \\ d DiSTAV, Dipartimento di Scienze della Terra, dell'Ambiente e della Vita, Università di Genova, Corso Europa 26, 16132 Genova, Italy \\ e Université Nice Sophia Antipolis, CNRS, FRE 3729 ECOMERS, Parc Valrose, 28 avenue Valrose, 06108 Nice cedex 02, France \\ ${ }^{\mathrm{f}}$ Université de Perpignan, CNRS, Via Domitia, Centre de Formation et de Recherche sur les Environnements Méditerranéens, UMR 5110, 66860 Perpignan cedex 9, France \\ g Office de l'Environnement de la Corse, Riserva Naturali di i Bucchi di Bunifaziu, Rundinara, 20169 Bonifacio, Corsica, France \\ ${ }^{\text {h }}$ Museum National d'Histoire Naturelle, Station Marine de Concarneau, 29900 Concarneau, France \\ i Departament d'Ecologia, Universitat de Barcelona, Diagonal 643, 08028 Barcelona, Spain
}

\section{A R T I C L E I N F O}

\section{Article history:}

Received 7 October 2016

Received in revised form 13 January 2017

Accepted 16 January 2017

Available online 9 February 2017

\section{Keywords:}

Photophilic algae

Marine Strategy Framework Directive (MSFD)

Biological indicator

Mediterranean Sea

\begin{abstract}
A B S T R A C T
A conceptual model was constructed for the functioning the algae-dominated rocky reef ecosystem of the Mediterranean Sea. The Ecosystem-Based Quality Index (reef-EBQI) is based upon this model. This index meets the objectives of the EU Marine Strategy Framework Directive. It is based upon (i) the weighting of each compartment, according to its importance in the functioning of the ecosystem; (ii) biological parameters assessing the state of each compartment; (iii) the aggregation of these parameters, assessing the quality of the ecosystem functioning, for each site; (iv) and a Confidence Index measuring the reliability of the index, for each site. The reef$\mathrm{EBQI}$ was used at 40 sites in the northwestern Mediterranean. It constitutes an efficient tool, because it is based upon a wide set of functional compartments, rather than upon just a few species; it is easy and inexpensive to implement, robust and not redundant with regard to already existing indices.
\end{abstract}

(c) 2017 Elsevier Ltd. All rights reserved.

\section{Introduction}

Coastal regions are subject to multiple and massive anthropogenic and natural pressures that may result in major ecosystem-wide changes (e.g. Worm and Lotze, 2006; Halpern et al., 2008; Derrien-Courtel et al., 2013; Giakoumi et al., 2015). These changes can include the loss of biodiversity, and alterations of ecosystem functioning and related services of benefit to society. Managing the quality of coastal waters and their ecosystems has become a challenge for many countries and governments (Bianchi et al., 2012; Parravicini et al., 2012; Vacchi et al., 2014; Giakoumi et al., 2015). Since the early 1990s, the European Union (EU) has adopted framework legislation for regulating human activities in the marine environment in order to guide them towards greater sustainability, by protecting and, wherever necessary, restoring good environmental quality. In the EU, the Habitats Directive (Habitats Directive,

\footnotetext{
* Corresponding author.

E-mail address: thierry.thibaut@univ.-amu.fr (T. Thibaut).
}

1992) established a list of habitats and species deserving protection, which provided a basis for designating areas in which these habitats and species had to be protected ('Natura 2000 sites'). The coverage of the marine realm by the Habitats Directive is insufficient, but more recently the EU Marine Strategy Framework Directive (MSFD, 2008) established a more comprehensive framework for the management and conservation of the marine environment. The MSFD is considered to be the environmental pillar of the Integrated Maritime Policy adopted in 2008 by the European Commission. The MSFD, with an Annex listing 11 descriptors, constitutes the basis for the assessment of 'Good Environmental Status' (GES) according to: (1) biodiversity; (2) nonindigenous species; (3) exploited fish and shellfish; (4) food webs; (5) human-induced eutrophication; (6) sea-floor integrity; (7) hydrographical conditions; (8) contaminants in water and sediment; (9) contaminants in fish and shellfish; (10) marine litter; and (11) introduction of energy/noise. The GES rating means that the marine environment is at the sustainable level, thus allowing uses and activities by current and future generations, i.e. the structure, functions and 
processes of the marine ecosystems, together with the associated physio-geographical, geographical, geological and climatic factors, allow those ecosystems to function efficiently and to maintain their resilience in the face of human induced environmental changes. The EU MSFD established a framework within which Member States agreed to take the appropriate measures to achieve or maintain GES in the marine realm by the year 2020 , at the latest.

Large canopy-forming species of kelp (Laminariales, Phaeophyceae, Stramenopiles) and fucoids (Fucales, Phaeophyceae, Stramenopiles) are dominant worldwide, in temperate areas, in most healthy shallow rocky reefs (Dayton, 1985; Steneck et al., 2002; Schiel and Foster, 2006; Derrien-Courtel, 2008; Harley et al., 2012; Derrien-Courtel et al., 2013). Kelps and fucoids are autogenic ecosystem engineers (Jones et al., 1994; Steneck et al., 2002). Their abundance and distribution are controlled by both top-down and bottom-up processes (Estes and Palmisano, 1974; Witman, 1987; Witman and Dayton, 2001; Steneck et al., 2002; Guidetti, 2006; Hereu et al., 2008; Vergés et al., 2009, 2014). A variety of human activities and global warming are responsible, directly or indirectly, for the worldwide decline of kelp and fucoid beds (e.g. Helmuth et al., 2006; Airoldi and Beck, 2007; Airoldi et al., 2008; Hawkins et al., 2008; Schiel, 2011; Lamela-Silvarrey et al., 2012; Thibaut et al., 2015; Vergés et al., 2016). Some taxa have even been driven to regional extinction (Thibaut et al., 2005; Coleman et al., 2008; Phillips and Blackshaw, 2011; Bianchi et al., 2014; Thibaut et al., 2015). A major consequence of these changes is a phase shift from a state with canopy forming species to alternative states, including barren grounds (e.g. Micheli et al., 2005; Sala et al., 2011, 2012; Boudouresque and Verlaque, 2013; Filbee-Dexter and Scheibling, 2014; Vergés et al., 2014). The shift from canopy forming states to barren ground states can present a hysteresis effect; this is the case for the extirpation of these forests by sea urchin overgrazing: the threshold in sea urchin density that induces the shift from canopy forests toward barren grounds is approximately one order of magnitude higher than the threshold density that allows the reverse shift from barren ground toward canopy forest (Ling et al., 2015).

Species of the genus Cystoseira (Fucales) are the main canopyforming macroalgae on the Mediterranean Sea shallow rocky reefs (e.g. Boudouresque, 1971a, 1971b; Verlaque, 1987; Ballesteros, 1988, 1990a, 1990b; Giaccone et al., 1994; Sales et al., 2012). The loss of Cystoseira beds has been reported throughout the Mediterranean Sea due to habitat destruction, eutrophication, damage by fishing nets and overgrazing by herbivores, leading to a shift to less structurally complex benthic assemblages, such as turf-forming, filamentous or other ephemeral seaweed assemblages or barren grounds where the regular sea urchin compartment (Paracentrotus lividus and Arbacia lixula) is one of the major drivers of habitat homogenization (e.g. Guidetti, 2006; Guidetti and Dulčić, 2007; Fraschetti et al., 2011; Giakoumi et al., 2012; Bianchi et al., 2014). This alteration of the structural complexity may in turn impair the functions associated with forested rocky reefs (e.g. spawning or nursery grounds) (Cheminée et al., 2013; Thiriet, 2014; Cuadros, 2015).

Where the decline of these canopy-forming species has been observed, the Mediterranean photophilic rocky reef assemblages are currently generally characterised by low stands of shrubby macrophytes (e.g. Cladostephus hirsutus, Corallina caespitosa, Dasycladus vermicularis, Dictyotales, Halopteris scoparia, Laurencia spp., Padina spp.) or by barren grounds with encrusting macrophytes (e.g. Aglaozonia stages of Cutleria spp., Lithophyllum incrustans, Neogoniolithon brassica-florida, Peyssonnelia rosa-marina, Pseudolithoderma adriaticum), sea urchins ( $P$. lividus and A. lixula) and Patella caerulea (e.g. Boudouresque, 1971a; Ballesteros, 1993; Bonaviri et al., 2011; Bianchi et al., 2012).

Environmental parameters, species composition and the ecosystem functioning can be profoundly altered by anthropogenic activities. Biological indicators are species or groups of species of which the distribution, function and abundance reflect possible alterations of the environment. A number of biological indicators are also adopted for monitoring biochemical, physiological or behavioural changes. The use of biological indicators concerns terrestrial, freshwater and marine habitats (e.g. White and Irvine, 2003; Diaz et al., 2004; Blanco et al., 2007; Martínez-Crego et al., 2010; Hoare et al., 2013).

In algae-dominated rocky reefs, macroalgae are commonly used as biological indicators to assess the ecological status of benthic assemblages. These indicators are multiple, using a panel of techniques ranging from quadrat sampling to in situ visual estimation of the assemblages (e.g. Díez et al., 2003; Ballesteros et al., 2007; Juanes et al., 2008; Orfanidis et al., 2011; Díez et al., 2012; Le Gal and Derrien-Courtel, 2015; Ar Gall et al., 2016; Blanfuné et al., 2016, and references therein). A further aim of seascape indicators using macroalgae is to provide information on the ecological status of the littoral zone (Cariou et al., 2013; Gobert et al., 2014). These indirect indicators are satisfactory for achieving specific goals (see above); however, their aim is not to reflect the structure and functioning of an ecosystem in pristine conditions or under anthropogenic stressors. Ecosystem-based indicators, taking into account the whole structure and functioning of the ecosystems, were recently developed for the meadows of the Mediterranean seagrass Posidonia oceanica (Personnic et al., 2014; Boudouresque et al., 2015a), underwater caves (Rastorgueff et al., 2015) and coralligenous habitats (Ruitton et al., 2014). This new category of indicators has been named 'Ecosystem Based Quality Indices' (EBQI).

The goal of the present study was not to develop a new method, nor to assess the relevance of the EBQI methodology, but to adopt it in the framework of a new category of ecosystem, the Mediterranean shallow, algae-dominated rocky reefs. Our aims here were to (i) establish a model of rocky reef composition, structure and functioning, (ii) identify the 'Good Environmental Status' for this ecosystem, (iii) define parameters and criteria needed for an ecosystem-based assessment of the quality of algae-dominated rocky reefs, (iv) propose an ecosystembased index, and then (v) apply this method to multiple sites across the NW Mediterranean Sea.

\section{Materials and methods}

\subsection{Conceptual model}

The habitat considered here includes the so-called photophilic infralittoral rocky environments, as defined by Pérès (1982). The limits of our study zone range between 1 and $10 \mathrm{~m}$ depth. The uppermost part of the infralittoral zone ( $<1 \mathrm{~m}$ depth) is excluded here, because it harbours particular assemblages with species adapted to particular and extremely variable conditions in relation to water movement, humectation, irradiance, salinity and temperature (Cefalì et al., 2016). Here we also exclude the deepest part of the infralittoral zone subjected to $<10 \%$ of the surface irradiance, because it is usually a transient zone to the circalittoral habitats and also because the key species of macro-herbivores are usually rare, resulting in low herbivore pressure (Boudouresque and Verlaque, 2013).

On the basis of information gathered from previous, generally quantitative, studies performed by the authors of this paper and others (e.g. Pérès, 1982; Verlaque and Nédelec, 1983; Sala and Boudouresque, 1997; Ruitton et al., 2000; Guidetti, 2004; Hereu et al., 2008; Bonaviri et al., 2009; Vergés et al., 2009; Agnetta et al., 2015; and references therein) and our own expert knowledge of algae-dominated rocky reefs, we constructed a conceptual model of the structure and functioning of northwestern Mediterranean algae-dominated rocky reefs (Fig. 1), which encompasses the following compartments:

- Multicellular Photosynthetic Organisms (MPOs) (box 1).

- Imported primary production from adjacent ecosystems (mostly Posidonia oceanica leaves and other marine MPOs).

- Bentho-pelagic Particulate and Dissolved Organic Matter (POM and DOM). 


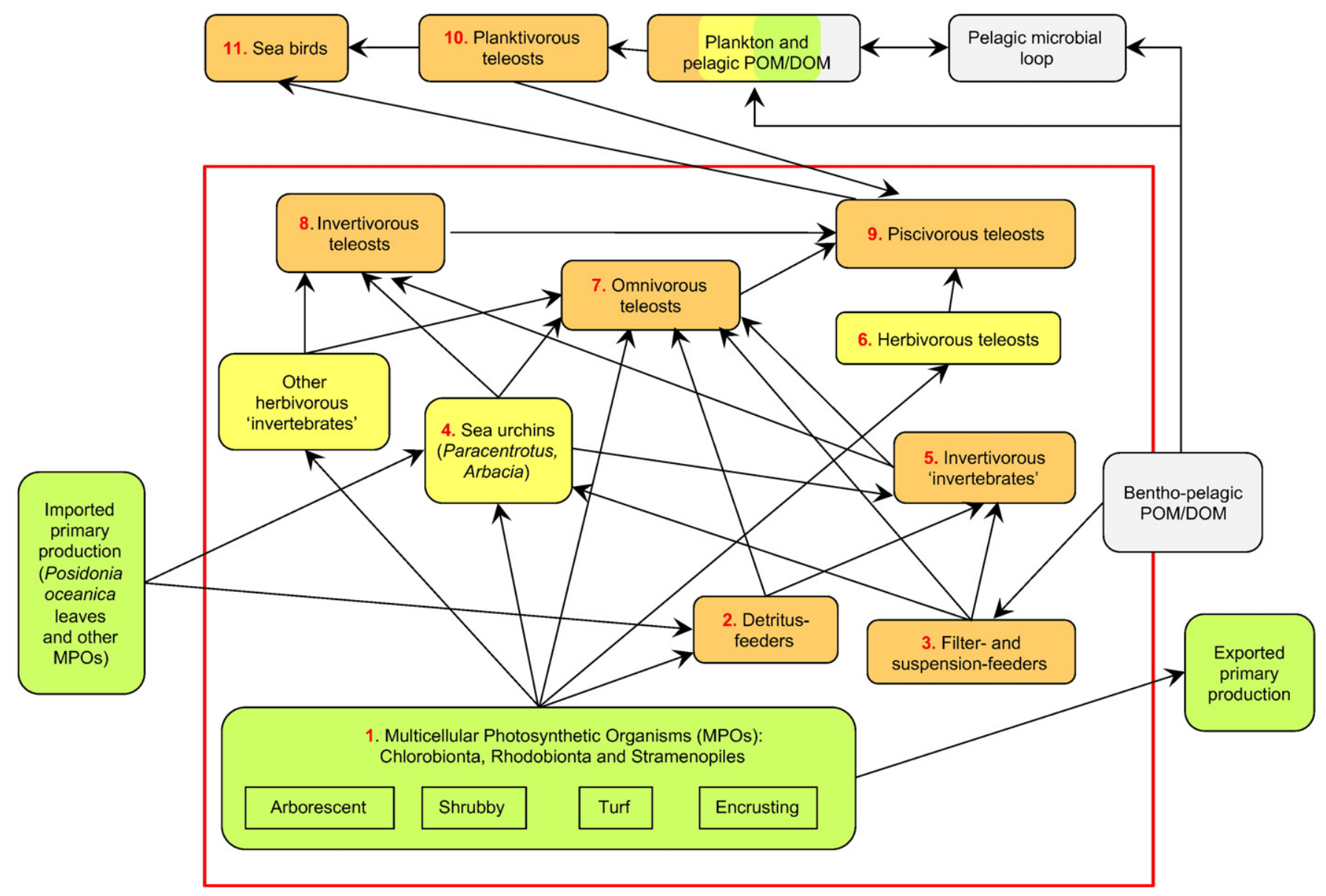

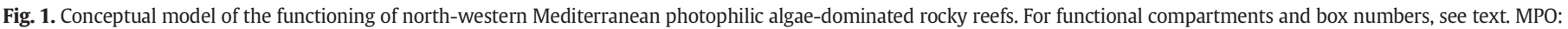

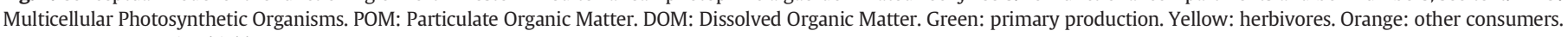
Grey: POM, DOM, microbial loop.

- Detritus-feeders (e.g. annelids, crustaceans, holothurians, brittle stars and the green spoonworm Bonellia viridis) (box 2).

- Filter- and suspension-feeders (e.g. bryozoans, sponges) (box 3).

- Sea urchins (Paracentrotus lividus and Arbacia lixula) (box 4).

- Other herbivorous 'invertebrates'1 (e.g. Patella caerulea).

- Invertivorous invertebrates (e.g. sea stars, gastropods, cephalopods, crustaceans) (box 5).

- Herbivorous teleosts (e.g. Sarpa salpa) (box 6).

- Omnivorous teleosts (e.g. Diplodus spp.) (box 7).

- Invertivorous teleosts, i.e. predators of invertebrates (e.g. most Labridae, Pagrus pagrus, Sparus aurata) (box 8).

- Piscivorous teleosts (e.g. Conger conger, Dentex dentex, Dicentrarchus labrax, Scorpaena spp., Serranus spp.) (box 9).

- Planktivorous teleosts (e.g. Chromis chromis, Spicara spp.) (box 10).

- Plankton (photosynthetic plankton and zooplankton) and non-living pelagic $\mathrm{POM}$ and $\mathrm{DOM}$.

- Pelagic microbial loop.

- Sea birds (e.g. the shags Phalacrocorax aristotelis desmarestii and $P$. carbo and the osprey, Pandion haliaetus) (box 11).

\subsection{Functional compartments considered (boxes)}

Only a subset of the functional compartments listed above (boxes 1 through 11) was considered for the assessment of the ecosystem status. For each compartment, one or two non-destructive methods were

\footnotetext{
1 'Invertebrates', though a commonly used term, constitute a paraphyletic set of metazoan taxa, not a taxon.
}

selected. Because most species display a marked seasonality, we selected late spring-early summer as the best period to perform the assessment. Trends of biotic parameters along an environmental quality gradient can present (i) a decreasing or increasing slope, from a very good to a low quality state, or (ii) a humpback shape, when intermediate values represent the very good state (Table 1 ). (See Table 2.)

\subsubsection{Multicellular Photosynthetic Organisms (MPOs) (box 1, Fig. 1)}

This compartment was estimated by the percentage cover of the different strata of MPOs: highest stratum, shrub-like stratum, turf stratum and encrusting stratum. MPOs correspond here to the customary notion of 'macroalgae', a highly polyphyletic complex of taxa, which encompasses the Phaeophyceae (brown algae) (kingdom Stramenopiles), the Rhodobionta (red algae) (kingdom Archaeplastida) and some Chlorobionta (green algae) (Boudouresque, 2015). The highest stratum encompasses perennial tree-like species in healthy environment such as Cystoseira spp., Sargassum spp., Digenea simplex and Halopithys incurva. Here we considered perennial species for which the main axes persist for more than one year, excluding the species surviving only by means of a basal part and those with upright parts living less than one year, although the individual can survive longer than one year through continuous renewal (e.g. Caulerpa spp.) (Meinesz, 1979). Thus, some tolerant perennial and non-perennial tree-like species that can thrive in disturbed conditions, e.g. Codium vermilara, Sphaerococcus coronopifolius, and invasive species, the proliferation of which can be independent of disturbance and stress, e.g. Asparagopsis spp. Caulerpa spp., Codium fragile, are excluded from this category. The shrub-like stratum encompasses species not considered before and those with a shrubby appearance, such as Cladostephus hirsutus (see Table S1 for further 
Table 1

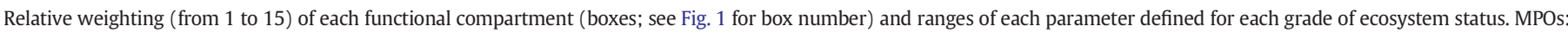
Multicellular Photosynthetic Organisms. POM: Particulate Organic Matter. DOM: Dissolved Organic Matter. WM: wet mass. Status: 4 (very good) through 0 (very low).

\begin{tabular}{|c|c|c|c|c|c|c|c|}
\hline Functional compartment & $\begin{array}{l}\text { Weigh-ting } \\
(\mathrm{W})\end{array}$ & Parameter & 4 & 3 & 2 & 1 & 0 \\
\hline 1- MPOs & 15 & Cover type & $\begin{array}{l}\text { Arborescent } \\
\text { perennial } \geq 50 \%\end{array}$ & $\begin{array}{l}\text { Arborescent } \\
\text { perennial } 5 \text { to }<50 \%\end{array}$ & $\begin{array}{l}\text { Shrubby } \\
\geq 50 \%\end{array}$ & $\begin{array}{l}\text { Shrubby } 5 \\
\text { to }<50 \%\end{array}$ & $\begin{array}{l}\text { Turf } \\
\text { Encrusting }\end{array}$ \\
\hline 2- Detritus-feeders & 3 & Density (individuals $10 \mathrm{~m}^{-2}$ ) & $<0.5$ & 0.5 to 1.0 & 1.1 to 2.0 & 2.1 to 5.0 & $>5.0$ \\
\hline 3- Filter- and suspension-feeders & 2 & Density (individuals $10 \mathrm{~m}^{-2}$ ) & $<2.5$ & 2.5 to 5.0 & 5.1 to 10.0 & 10.1 to 20.0 & $>20.0$ \\
\hline 4- Sea urchins & 10 & Density (individuals $\mathrm{m}^{-2}$ ) & 0.05 to 1.0 & $<0.05$ & 1.1 to 5.0 & 5.1 to 10.0 & $>10.0$ \\
\hline 5- Invertivorous invertebrates & 3 & & & & & & \\
\hline $\begin{array}{l}\text { - Octopus vulgaris, Marthasterias } \\
\text { glacialis }\end{array}$ & & Density (individuals $200 \mathrm{~m}^{-2}$ ) & $>1.0$ & 0.6 to 1.0 & 0.3 to 0.5 & 0.1 to 0.2 & $<0.1$ \\
\hline - Hexaplex trunculus & & Density (individuals $10 \mathrm{~m}^{-2}$ ) & $<0.5$ & 0.6 to 1.0 & 1.1 to 2.0 & 2.1 to 4.0 & $>4.0$ \\
\hline 6- Herbivorous teleosts & 4 & Biomass $\mathrm{kg}$ teleosts WM $100 \mathrm{~m}^{-2}$ & 1.1 to 3.0 & 3.1 to 4.0 & $>4.0$ & 0.25 to 1.0 & $<0.25$ \\
\hline $\begin{array}{l}\text { 7-8- Omnivorous and } \\
\text { Invertivorous teleosts }\end{array}$ & 4 & Biomass $\mathrm{kg}$ teleosts WM $100 \mathrm{~m}^{-2}$ & $>3.5$ & 2.6 to 3.5 & 1.6 to 2.5 & 0.8 to 1.5 & $<0.8$ \\
\hline 9- Piscivorous teleosts & 7 & Biomass $\mathrm{kg}$ teleosts WM $100 \mathrm{~m}^{-2}$ & $>5.0$ & 1.0 to 5.0 & 0.5 to 0.9 & 0.4 to 0.1 & $<0.1$ \\
\hline 10- Planktivorous teleosts & 1 & Biomass $\mathrm{kg}$ teleosts WM $100 \mathrm{~m}^{-2}$ & $>2.0$ & 2.0 to 1.5 & 1.5 to 0.9 & 0.9 to 0.3 & $<0.3$ \\
\hline 11- Sea birds & 1 & & & & & & \\
\hline - Phalacrocorax spp. & & Distance to the nearest nesting site (km) & $<4.0$ & 4.0 to 7.9 & 8.0 to 12.9 & 13.0 to 17.0 & $>17.0$ \\
\hline - Pandion haliaetus & & Distance to the nearest nesting site (km) & $<4.0$ & 4.0 to 7.9 & 8.0 to 12.9 & 13.0 to 17.0 & $>17.0$ \\
\hline
\end{tabular}

taxa). The turf stratum (see Littler and Littler, 1980 and Connell et al., 2014 for definitions) is constituted by filamentous ephemeral species such as Ectocarpaceae (see Table S1 for further taxa). The encrusting stratum is constituted by encrusting Phaeophyceae and encrusting red algae (see Table $\mathrm{S} 1$ for taxa).

When assessing the status of the MPO box, the score is determined by the highest stratum present since the others are developing beneath (Table 1).

\subsubsection{Detritus-feeders (box 2, Fig. 1)}

Detritus-feeders constitute a diverse set of organisms. Here, holothurians feeding on macro-detritus and sediments (Holothuria forskali, H. poli, H. tubulosa) were used as a proxy, as they are easy to count. Other detritus-feeders such as Ophiuroidea and Bonellia viridis were not used since their abundance is often difficult to assess. The abundance of Holothuria spp. on algae-dominated rocky reefs is correlated with the presence of sediment and detritus. Their frequency will be high in areas exposed to high sedimentation (rocky reefs close to soft substrates and seagrass beds, continental inputs and coastal constructions). Thus, the descriptor used for this box is the density of Holothuria spp.

The density of detritus-feeders can be measured within the same quadrats as the sea urchins (see below, box 4) (Table 1).

\subsubsection{Filter- and suspension-feeders (box 3, Fig. 1)}

A number of benthic filter- and suspension-feeders dwell on algae-dominated rocky reefs, either directly attached to the substrate or as epibionts. They belong to different taxonomic groups (e.g. annelids, ascidians, bryozoans, bivalves, cnidarians, barnacles, gastropods, sponges). To make an assessment of this box, we used the density of large $(>5 \mathrm{~cm})$ (see Table S1 for taxa).

Table 2

Criteria to assess the Confidence Index (CI) of the status of a compartment (box).

\begin{tabular}{ll}
\hline $\mathrm{CI}$ & Criteria \\
\hline 4 & Field data available, recent and suitable with the recommended methods \\
3 & Field data recent, partially completed with expert judgment \\
2 & No quantitative field data but recent expert judgment \\
1 & No quantitative field data, but earlier expert judgment \\
0 & No quantitative field data and no suitable expert judgment
\end{tabular}

The density of filter- and suspension-feeders can be measured within the same quadrats as the sea urchins (see below, box 4) (Table 1).

\subsubsection{Sea urchins (box 4, Fig. 1)}

The regular sea urchins Paracentrotus lividus and Arbacia lixula, and to a much lesser extent Sphaerechinus granularis, are the main invertebrate grazers in Mediterranean algae-dominated rocky reefs. Sea urchins are capable of assimilating organic matter through their porous spines, enabling them to thrive in polluted waters and within habitats that are poor in primary producers (De Burgh, 1975; West et al., 1977; Régis, 1978, 1986). The abundance of these species is controlled by some fish, crustaceans, molluscs and other echinoderms (Dance and Savy, 1987; Sala, 1997; Guidetti, 2004; Hereu Fina, 2004; Hereu et al., 2005). Overfishing of sea urchin predators, and possibly organic matter pollution, can result in sea urchin outbreaks, which wipe out most erect algae, inducing barren grounds (Sala et al., 1998; Gianguzza et al., 2011, Boudouresque and Verlaque, 2013). Once established, barren grounds can be maintained by quite low sea urchin densities (Bulleri et al., 1999; Ruitton et al., 2000; Bonaviri et al., 2011).

The density of sea urchins was assessed within 1- $\mathrm{m}^{2}$ quadrats, with 30 replicates placed randomly (Table 1 ). The census considered only the individuals $>3 \mathrm{~cm}$ (test diameter without spines), because small individuals can be hidden within crevices, under pebbles, and in the understorey, generating a possible bias in the census. The parameter ranges, within the status scale, are assessed on the basis of the literature (Verlaque and Nédelec, 1983; Verlaque, 1987; Palacin et al., 1998; Sala et al., 1998; Ruitton et al., 2000; Hereu et al., 2012; Boudouresque and Verlaque, 2013) and unpublished data of the authors of the present article.

\subsubsection{Invertivorous invertebrates (box 5, Fig. 1)}

Invertivorous invertebrates (=invertebrate carnivores preying on invertebrates) are abundant and diverse in the rocky infralittoral zone. The cephalopod Octopus vulgaris is a predator of molluscs, crustaceans and, to a lesser extent, other invertebrates and fish (Ambrose and Nelson, 1983). The gastropod Hexaplex trunculus is a predator of molluscs and sea urchins (Morton et al., 2007). The sea star Marthasterias glacialis preys on sea urchins and molluscs (Dance and Savy, 1987; Savy, 1987; Guidetti, 2004; Bonaviri et al., 2009) (see Table S1 for other invertivorous invertebrates). Three species (Octopus vulgaris, Hexaplex trunculus, and Marthasterias glacialis) were used as a proxy of the box, as they are easy to count. Hexaplex trunculus is favoured by disturbances as well as the abundance of its preferred prey Mytilus 
Table 3

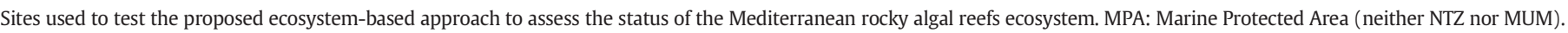

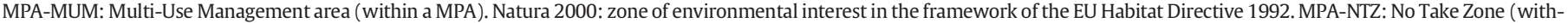
in a MPA).

\begin{tabular}{|c|c|c|c|c|c|c|}
\hline Number & Country-region & Site & Latitude & Longitude & Year of sampling & Protection level \\
\hline 1 & Spain - Balearic Islands & Ses Bledes Islets, Ibiza & $38^{\circ} 58^{\prime} 40.16^{\prime \prime} \mathrm{N}$ & $1^{\circ} 9^{\prime} 36.42^{\prime \prime} \mathrm{E}$ & 2010 & Natura 2000 \\
\hline 2 & Spain - Balearic Islands & Espardell Islet, Formentera & $38^{\circ} 47^{\prime} 44.54^{\prime \prime} \mathrm{N}$ & $1^{\circ} 28^{\prime} 48.11^{\prime \prime} \mathrm{E}$ & 2005 & MPA-NTZ \\
\hline 3 & Spain - Balearic Islands & Punta Prima, Formentera & $38^{\circ} 43^{\prime} 41.60^{\prime \prime} \mathrm{N}$ & $1^{\circ} 28^{\prime} 15.32^{\prime \prime} \mathrm{E}$ & 2005 & $\mathrm{MPA}^{\mathrm{a}}$ \\
\hline 4 & Spain - Balearic Islands & Cap de Llebeig, Dragonera Islet, Mallorca & $39^{\circ} 34^{\prime} 20.34^{\prime \prime} \mathrm{N}$ & $2^{\circ} 18^{\prime} 5.76^{\prime \prime} \mathrm{E}$ & 2003 & Natura 2000 \\
\hline 5 & Spain - Balearic Islands & Formentor, Mallorca & $39^{\circ} 57^{\prime} 36.84^{\prime \prime} \mathrm{N}$ & $3^{\circ} 12^{\prime} 57.73^{\prime \prime} \mathrm{E}$ & 2004 & Natura 2000 \\
\hline 6 & Spain - Balearic Islands & Ses Rates, Cabrera Island & $39^{\circ} 7^{\prime} 57.17^{\prime \prime} \mathrm{N}$ & $2^{\circ} 55^{\prime} 25.07^{\prime \prime} \mathrm{E}$ & 2004 & MPA-NTZ \\
\hline 7 & Spain - Balearic Islands & Cap Gros, Menorca & $40^{\circ} 3^{\prime} 52.42^{\prime \prime} \mathrm{N}$ & $3^{\circ} 56^{\prime} 4.65^{\prime \prime} \mathrm{E}$ & 2004 & MPA-NTZ \\
\hline 8 & Spain - Balearic Islands & Cavalleria, Menorca & $40^{\circ} 3^{\prime} 59.62^{\prime \prime} \mathrm{N}$ & $4^{\circ} 3^{\prime} 35.35^{\prime \prime} \mathrm{E}$ & 2004 & $\mathrm{MPA}^{\mathrm{a}}$ \\
\hline 9 & Spain - Balearic Islands & Favàritx, Menorca & $39^{\circ} 59^{\prime} 52.65^{\prime \prime} \mathrm{N}$ & $4^{\circ} 16^{\prime} 5.23^{\prime \prime} \mathrm{E}$ & 2003 & Natura 2000 \\
\hline 10 & Spain - Balearic Islands & Illa de l'Aire, Menorca & $39^{\circ} 48^{\prime} 10.93^{\prime \prime} \mathrm{N}$ & $4^{\circ} 17^{\prime} 37.54^{\prime \prime} \mathrm{E}$ & 2004 & Natura 2000 \\
\hline 11 & Spain - Catalonia & Tossa de Mar & $41^{\circ} 43^{\prime} 13.96^{\prime \prime} \mathrm{N}$ & $2^{\circ} 56^{\prime} 24.56^{\prime \prime} \mathrm{E}$ & 2005 & Natura 2000 \\
\hline 12 & Spain - Catalonia & Medes Islands, Estartit & $42^{\circ} 2^{\prime} 41.52^{\prime \prime} \mathrm{N}$ & $3^{\circ} 13^{\prime} 28.06^{\prime \prime} \mathrm{E}$ & 2009 & MPA-NTZ \\
\hline 13 & France - French Catalonia & Cap Rederis, Banyuls-sur-Mer & $42^{\circ} 27^{\prime} 52.43^{\prime \prime} \mathrm{N}$ & $3^{\circ} 9^{\prime} 46.64^{\prime \prime} \mathrm{E}$ & 2015 & MPA-NTZ \\
\hline 14 & France - French Catalonia & Cap l'Abeille, Banyuls-sur-Mer & $42^{\circ} 28^{\prime} 31.41^{\prime \prime} \mathrm{N}$ & $3^{\circ} 9^{\prime} 20.11^{\prime \prime} \mathrm{E}$ & 2015 & MPA-MUM \\
\hline 15 & France - French Catalonia & Cap Béar South, Port-Vendres & $42^{\circ} 30^{\prime} 54.46^{\prime \prime} \mathrm{N}$ & $3^{\circ} 8^{\prime} 26.84^{\prime \prime} \mathrm{E}$ & 2015 & Natura $2000^{\mathrm{b}}$ \\
\hline 16 & France - Western Provence & Méjean, Ensuès-la Redonne & $43^{\circ} 19^{\prime} 45.38^{\prime \prime} \mathrm{N}$ & $5^{\circ} 13^{\prime} 2.26^{\prime \prime} \mathrm{E}$ & 1999 & Natura 2000 \\
\hline 17 & France - Western Provence & Corbière harbour, Marseille & $43^{\circ} 21^{\prime} 29.97^{\prime \prime} \mathrm{N}$ & $5^{\circ} 17^{\prime} 57.44^{\prime \prime} \mathrm{E}$ & 1999 & \\
\hline 18 & France - Western Provence & Digue des Catalans, Marseille & $43^{\circ} 17^{\prime} 24.37^{\prime \prime} \mathrm{N}$ & $5^{\circ} 20^{\prime} 55.57^{\prime \prime} \mathrm{E}$ & 1999 & \\
\hline 19 & France - Western Provence & Pointe Rouge harbour pier, Marseille & $43^{\circ} 14^{\prime} 40.29^{\prime \prime} \mathrm{N}$ & $5^{\circ} 21^{\prime} 44.60^{\prime \prime} \mathrm{E}$ & 1999 & \\
\hline 20 & France - Western Provence & Goudes harbour pier, Marseille & $43^{\circ} 13^{\prime} 0.07^{\prime \prime} \mathrm{N}$ & $5^{\circ} 20^{\prime} 39.95^{\prime \prime} \mathrm{E}$ & 1999 & Natura 2000 \\
\hline 21 & France - Western Provence & Callelongue, Marseille & $43^{\circ} 12^{\prime} 39.87^{\prime \prime} \mathrm{N}$ & $5^{\circ} 21^{\prime} 7.77^{\prime \prime} \mathrm{E}$ & 1999 & $\mathrm{MPA}^{\mathrm{c}}$ \\
\hline 22 & France - Eastern Provence & Pointe Montrémian, Bagaud island & $43^{\circ} 1^{\prime} 5.93^{\prime \prime} \mathrm{N}$ & $6^{\circ} 21^{\prime} 48.99^{\prime \prime} \mathrm{E}$ & 2015 & MPA-MUM \\
\hline 23 & France - Eastern Provence & Bagaud east, Bagaud Island & $43^{\circ} 0^{\prime} 31.03^{\prime \prime} \mathrm{N}$ & $6^{\circ} 21^{\prime} 53.21^{\prime \prime} \mathrm{E}$ & 2015 & MPA-MUM \\
\hline 24 & France - Eastern Provence & Pointe du Tuff, Port-Cros Island & $43^{\circ} 0^{\prime} 13.83^{\prime \prime} \mathrm{N}$ & $6^{\circ} 24^{\prime} 49.70^{\prime \prime} \mathrm{E}$ & 2015 & MPA-MUM \\
\hline 25 & France - Eastern Provence & Pointe du Vaisseau, Port-Cros Island & $42^{\circ} 59^{\prime} 35.65^{\prime \prime} \mathrm{N}$ & $6^{\circ} 24^{\prime} 10.70^{\prime \prime} \mathrm{E}$ & 2015 & MPA-MUM \\
\hline 26 & France - Eastern Provence & Gabinière Islet, Port-Cros Island & $42^{\circ} 59^{\prime} 16.38^{\prime \prime} \mathrm{N}$ & $6^{\circ} 23^{\prime} 36.29^{\prime \prime} \mathrm{E}$ & 2014 & MPA-MUM \\
\hline 27 & France - French Riviera & Pointe Galère, Théoule-sur-Mer & $43^{\circ} 29^{\prime} 47.28^{\prime \prime} \mathrm{N}$ & $6^{\circ} 57^{\prime} 16.82^{\prime \prime} \mathrm{E}$ & 1999 & \\
\hline 28 & France - French Riviera & Vieux Port pier, Cannes & $43^{\circ} 32^{\prime} 45.21^{\prime \prime} \mathrm{N}$ & $7^{\circ} 0^{\prime} 50.65^{\prime \prime} \mathrm{E}$ & 1999 & \\
\hline 29 & France - French Riviera & Canto harbour pier, Cannes & $43^{\circ} 32^{\prime} 20.23^{\prime \prime} \mathrm{N}$ & $7^{\circ} 1^{\prime} 48.94^{\prime \prime} \mathrm{E}$ & 1999 & \\
\hline 30 & France - French Riviera & Batéguier, Sainte-Marguerite Island & $43^{\circ} 31^{\prime} 25.49^{\prime \prime} \mathrm{N}$ & $7^{\circ} 1^{\prime} 55.17^{\prime \prime} \mathrm{E}$ & 1999 & Natura 2000 \\
\hline 31 & France - French Riviera & Le Lido, Saint-Jean-Cap-Ferrat & $43^{\circ} 41^{\prime} 30.75^{\prime \prime} \mathrm{N}$ & $7^{\circ} 19^{\prime} 16.07^{\prime \prime} \mathrm{E}$ & 2011 & Natura 2000 \\
\hline 32 & Italy - Liguria & Bergeggi, Savona & $44^{\circ} 14^{\prime} 13.92^{\prime \prime} \mathrm{N}$ & $8^{\circ} 26^{\prime} 36.82^{\prime \prime} \mathrm{E}$ & 2008-2014 & MPA \\
\hline 33 & Italy - Liguria & Portofino, Genoa & $44^{\circ} 17^{\prime} 55.27^{\prime \prime} \mathrm{N}$ & $9^{\circ} 12^{\prime} 57.96^{\prime \prime} \mathrm{E}$ & $1990-1993$ & \\
\hline 34 & Italy - Liguria & Portofino, Genoa & $44^{\circ} 17^{\prime} 55.27^{\prime \prime} \mathrm{N}$ & $9^{\circ} 12^{\prime} 57.96^{\prime \prime} \mathrm{E}$ & $2008-2014$ & MPA \\
\hline 35 & France - Corsica & Garganellu Islet, Scandola, Osani & $42^{\circ} 21^{\prime} 52.92^{\prime \prime} \mathrm{N}$ & $8^{\circ} 32^{\prime} 24.46^{\prime \prime} \mathrm{E}$ & 2015 & MPA-NTZ \\
\hline 36 & France - Corsica & Patrimonio & $42^{\circ} 42^{\prime} 53.12^{\prime \prime} \mathrm{N}$ & $9^{\circ} 19^{\prime} 17.97^{\prime \prime} \mathrm{E}$ & 2015 & Natura 2000 \\
\hline 37 & France - Corsica & U Grecu, Lavezzu Island & $41^{\circ} 20^{\prime} 42.44^{\prime \prime} \mathrm{N}$ & $9^{\circ} 15^{\prime} 30.12^{\prime \prime} \mathrm{E}$ & 2010 & MPA-MUM \\
\hline 38 & France - Corsica & North Bruzi Islands, Pianottoli-Caldarello & $41^{\circ} 27^{\prime} 51.04^{\prime \prime} \mathrm{N}$ & $8^{\circ} 54^{\prime} 57.70^{\prime \prime} \mathrm{E}$ & 2010 & MPA-NTZ \\
\hline 39 & France - Corsica & East Bruzi Islands, Pianottoli-Caldarello & $41^{\circ} 27^{\prime} 47.18^{\prime \prime} \mathrm{N}$ & $8^{\circ} 54^{\prime} 53.40^{\prime \prime} \mathrm{E}$ & 2010 & MPA-NTZ \\
\hline 40 & Italy - Sardinia & Punta Marginetto, La Maddalena & $41^{\circ} 15^{\prime} 28.75^{\prime \prime} \mathrm{N}$ & $9^{\circ} 24^{\prime} 19.88^{\prime \prime} \mathrm{E}$ & 2010 & MPA \\
\hline
\end{tabular}

a Only recreational fishing, purse seine and trawling are forbidden.

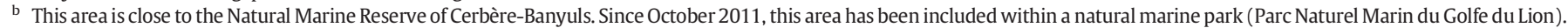

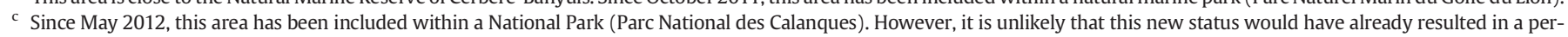
ceptible effect.

galloprovincialis (Peharda and Morton, 2006). In contrast, Octopus vulgaris and Marthasterias glacialis are common in healthy environments.

The density of Hexaplex trunculus was measured within the same quadrats as the sea urchins (see above, box 4); only individuals $>3 \mathrm{~cm}$ in height were considered. The abundance of Octopus vulgaris and Marthasterias glacialis was assessed within the same transects as teleosts (see below, box 6-10) (Table 1).

Table 4

Contingency table of the study sites as a function of the level of protection and the ecological status (reef-EBOI). MPA: Marine Protected Area (neither NTZ nor MUM). MPA-MUM: Multi-Use Management area (within a MPA). Natura 2000: zone of environmental interest in the framework of the EU Habitat Directive 1992. MPA-NTZ: No Take Zone (within a MPA).

\begin{tabular}{llllll}
\hline Ecological Status & No protection & Natura 2000 & MPA & MPA-MUM & MPA-NTZ \\
\hline Bad and poor & 2 & 4 & 1 & 0 & 1 \\
Moderate & 5 & 7 & 4 & 1 & 0 \\
Good and high & 0 & 1 & 1 & 6 & 7 \\
\hline
\end{tabular}

2.2.6. Teleosts (comprising herbivores, omnivores, invertivores, piscivores and planktivores) (boxes 6 to 10, Fig. 1)

The spatial and temporal distribution of teleosts on algae-dominated rocky reefs varies depending on day and night time, season and depth (Francour et al., 1995; Ruitton et al., 2000). Teleosts were grouped into five functional groups according to the trophic habits of adults. Herbivores (box 6, Fig. 1) include species with a diet dominated by MPOs (macroalgae and seagrasses). Salpa salpa is the only species of this group to be common in the NW Mediterranean (see Table S1 for further comments), Omnivores (box 7, Fig. 1) show a relatively diverse diet and include Diplodus spp. and Mugilidae. Invertivores (teleost predators of invertebrates; box 8, Fig. 1.) include species whose diet is constituted by invertebrates such as annelids, crustaceans and molluscs (see Table S1 for taxa). Boxes 7 and 8 are estimated together to define the status of the group omnivorous and invertivorous teleosts. Piscivores (box 9, Fig. 1) preferably prey on fish, even if they also consume invertebrates (e.g. Cephalopods, Crustaceans) (see Table S1 for taxa). Planktivores (box 10, Fig. 1) include two categories: the exclusive zooplankton feeders and omnivorous feeders, which consume both zooplankton and POM (see Table S1 for taxa).

Harmelin-Vivien and Francour (1992) emphasized the sensitivity of the assessment of the composition and trophic structure of teleost fish 
Table 5

Comparison between the reef EBQI and the CARLIT index, and the corresponding ecological status, for the study sites of France (French Catalonia, Provence, French Riviera and Corsica). CARLIT index data from Thibaut et al. (2008, 2010, 2011), Thibaut and Markovic (2009), Thibaut and Blanfuné (2014).

\begin{tabular}{|c|c|c|c|c|c|}
\hline \multirow[t]{2}{*}{ Site } & \multirow[t]{2}{*}{ Water body } & \multicolumn{2}{|c|}{ Reef EBQI } & \multicolumn{2}{|c|}{ CARLIT index } \\
\hline & & EBQI & Ecological status & EQR & Ecological status \\
\hline 13 & FRDC01 & 7.40 & Good & 0.58 & Moderate \\
\hline 14 & FRDC01 & 6.85 & Good & 0.58 & Moderate \\
\hline 15 & FRDC01 & 3.10 & Bad & 0.58 & Moderate \\
\hline 16 & FRDC05 & 3.95 & Poor & 0.61 & Good \\
\hline 17 & FRDC05 & 4.55 & Moderate & 0.61 & Good \\
\hline 18 & FRDC06a & 3.58 & Poor & 0.43 & Moderate \\
\hline 19 & FRDC06b & 5.65 & Moderate & 0.64 & Good \\
\hline 20 & FRDC06b & 2.18 & Bad & 0.64 & Good \\
\hline 21 & FRDC07a & 3.70 & Poor & 0.80 & High \\
\hline 22 & FRDC07h & 6.10 & Good & 1.00 & High \\
\hline 23 & FRDC07h & 6.35 & Good & 1.00 & High \\
\hline 24 & FRDC07h & 6.95 & Good & 1.00 & High \\
\hline 25 & FRDC07h & 5.65 & Moderate & 1.00 & High \\
\hline 26 & FRDC07h & 7.50 & High & 1.00 & High \\
\hline 27 & FRDC08d & 3.90 & Poor & 0.93 & High \\
\hline 28 & FRDC08e & 5.95 & Moderate & 0.82 & High \\
\hline 29 & FRDC08e & 5.50 & Moderate & 0.82 & High \\
\hline 30 & FRDC08e & 4.15 & Poor & 0.82 & High \\
\hline 31 & FRDC09d & 5.83 & Moderate & 0.43 & Moderate \\
\hline 35 & FREC04ac & 7.50 & High & 0.96 & High \\
\hline 36 & FREC01c & 7.65 & High & 0.69 & Good \\
\hline 37 & FREC03ad & 6.53 & Good & 0.80 & High \\
\hline 38 & FREC03eg & 4.38 & Poor & 0.94 & High \\
\hline 39 & FREC03eg & 6.63 & Good & 0.94 & High \\
\hline
\end{tabular}

assemblages to the methodology used. Teleosts were estimated via visual censuses (see Harmelin-Vivien et al., 1985 for methodological details) during day-time (10:00 to 16:00 UT) in the warm season (end of spring and summer). All teleosts were counted within 25 -m linear and $4-\mathrm{m}$ wide transects, with 10 replicates per site. Total length of individuals (to the nearest $2 \mathrm{~cm}$ ) and the number of individuals per species were recorded.

\subsubsection{Sea birds (box 11, Fig. 1)}

Shags (Phalacrocorax spp.) and ospreys (Pandion haliaetus) directly interact with the algae-dominated rocky reefs. Shags feed on pelagic planktivorous teleosts; they can also dive and feed on benthic teleosts (Guyot, 1990; Morat, 2007; Morat et al., 2011). Ospreys are opportunistic fish-eating birds that mainly consume Mugilidae, Diplodus spp. and Sarpa salpa (Francour and Thibault, 1995, 1996; Thibault et al., 2001). In contrast, other sea birds, such as Larus spp. and Puffinus spp., feed on offshore pelagic species and are therefore not considered here.

The sea bird compartment is estimated via the distance of the nearest nesting site of Phalacrocorax spp. and Pandion haliaetus from the study site (Table 1 ).

\subsection{Compartments not considered}

\subsubsection{Imported primary production from adjacent ecosystems (Posidonia oceanica leaves and other MPOs)}

The Posidonia oceanica ecosystem exports huge amounts of organic matter, mainly in the form of $P$. oceanica dead leaves, but also leaf epibionta and seaweeds living on rhizomes, towards adjacent ecosystems, in particular algae-dominated rocky reefs (Personnic et al., 2014; Boudouresque et al., 2015b). There, dead P. oceanica leaves can represent a conspicuous part, up to $40 \%$, of the diet of the sea urchin Paracentrotus lividus (Nédelec, 1982; Verlaque and Nédelec, 1983; Boudouresque and Verlaque, 2013).

\subsubsection{Other herbivorous invertebrates}

Other herbivorous invertebrates are involved in MPO consumption (Ledoyer, 1966; Bellan-Santini, 1969; Pitacco et al., 2014). Among
Mollusca, the limpet Patella caerulea can be common in clearings within the macroalgal cover, and also on barren grounds. However, limpets are unable to open up such clearings and depend upon sea urchins for this task (Verlaque, 1987). Haliotis tuberculata lamellosa, Bolma rugosa and Cerithium vulgatum are grazers commonly found under the pebbles and in the understorey of erect macroalgae. Aplysia punctata swims over and browses MPOs (Carefoot, 1987). In contrast, the crustacean decapod Acanthonyx lunulatus browses in the upper branches of erect Phaeophyceae (Chaix, 1979) (see Table S1 for further taxa). Both because their abundance is closely related to the abundance of erect MPOs and because their abundance is difficult to measure, herbivorous invertebrates other than sea urchins have not been considered in this protocol.

2.3.3. Plankton (photosynthetic plankton and zooplankton), non-living pelagic Particulate Organic Matter (POM) and the pelagic microbial loop

The planktonic food web (from phytoplankton to zooplankton) and the non-living POM are the basis for the feeding of planktivorous fish, such as Chromis chromis, Spicara maena and S. smaris and of omnivorous fish consuming plankton and POM, such as Boops boops (Khoury, 1987; Cresson et al., 2014). Some planktonic organisms are larval forms of benthic taxa (meroplankton). This compartment is highly seasonal and estimates would be time-consuming. It is better assessed through its consumers (box 10). For the same reasons, the pelagic microbial loop, which partly depends upon the bentho-pelagic POM-DOM (Velimirov, 1984), has not been specifically assessed.

\subsection{The Ecosystem-Based Quality Index (reef-EBQI)}

The rationale governing our ecosystem-based approach is the same as that described for Posidonia meadows (Personnic et al., 2014), coralligenous reefs (Ruitton et al., 2014), and submarine caves (Rastorgueff et al., 2015): (i) quantifying and assessing a set of compartments (boxes) of the conceptual model by means of a set of parameters, (ii) balancing their relative weighting and (iii) using a simple algorithm to calculate a rank for the ecosystem status within a given area from Bad to High, in compliance with the five Ecological Statuses of the Water Framework Directive (WFD). As the methodological corpus for the calculation of the reef-EBQI is similar to that of the Posidonia-EBQI and the cave-EBQI, details are to be found in Supplementary material S1, including the necessary adjustments related to the specificity of the algaedominated rocky reef conceptual model.

In order to test the efficiency of the proposed method, it has been applied to 40 sites (Fig. 2, Table 3) using a variety of data sources (published, unpublished, expert judgment). For each site, data were collected during a short time period (late spring-early summer) of a given year (in some rare cases, a few successive years). These data were collected over two decades (1999 to 2015), with the aim testing the method and assessing changes over time when applicable.

A site is defined as an algae-dominated rocky reef between 1 and $10 \mathrm{~m}$ depth, covering about two hectares. The sites are localized in the north-western Mediterranean Sea, from Spain to Italy, including the Balearic Islands, Corsica and Sardinia (Fig. 2). This area is considered as relatively biogeographically homogeneous. The sites also cover a wide range of human pressure and protection statuses, ranging from artificial substrates (e.g. harbour pier) to Natura 2000 sites, Marine Protected Areas (MPAs), Multi-Use Management areas (MPA-MUM), and No-Take zones (MPA-NTZ) (Table 3). For Natura 2000 sites, there is no planned regulation of fishing and no specific regulation regarding the protection of species of algae-dominated rocky reefs (Meinesz and Blanfuné, 2015). Mediterranean MPAs are often weakly enforced if not mere 'paper parks', where the protection measures are not properly enforced (Guidetti et al., 2008; Montefalcone et al., 2009; Sala et al., 2012); it is worth emphasizing that most MPAs taken into account in the present study are well enforced, either No-Take zones (MPA-NTZ), where all fishing activities are prohibited (sites number 2, 6, 7, 12, 13, 


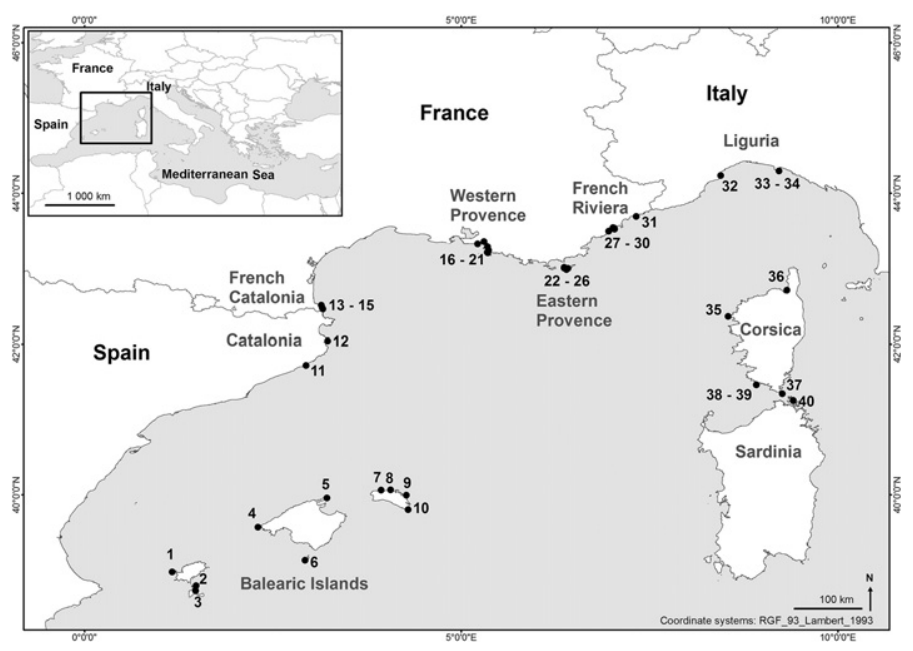

Fig. 2. Localization of the study sites.

35, 38, 39; Table 3), or Multi-Use Managed (MPA-MUM) areas (sites number 14, 22 to 26,37), where most recreational fishing is prohibited and artisanal fishing is allowed but strictly limited (Boudouresque et al., 2004; Cadiou et al., 2009).

The correlation between reef-EBQI and $\mathrm{Cl}_{-\mathrm{EBOI}}$ was tested using the Spearman test. A Correspondence Analysis (CA) was performed to study the relationship between the level of protection and the ecological status. In order to follow the assumptions of the CA (e.g. to avoid getting classes with frequency equal to zero), the following classes of ecological status were combined: High + Good and Bad + Poor. Analyses were performed using Statistica V.10 software.

\section{Results}

On the basis of the reef-EBQI, the 40 sites are distributed in the 5 following ecological quality classes: 2 sites are classed as Bad (reefEBQI $<3.5$ ), 6 sites are classed as Poor $(3.5 \geq$ reef-EBQI $<4.5)$, 17 sites are classed as Moderate ( $4.5 \geq$ reef-EBQI $<6$ ), 10 sites are classed as Good $(6.0 \geq$ reef-EBQI $<7.5)$ and 5 sites are classed as High (reefEBQI $\geq 7.5$ ) (Table 3, Fig. 3).

These reef-EBQI values are accompanied by a value of Confidence Index (CI: Fig. 3) makes them more user-friendly. No significant correlation ( $p>0.05$, Spearman correlation test) was detected between the reef-EBQI and its $\mathrm{CI}$.

The Correspondence Analysis of the relationship between ecological status and protection status (Table 4, Fig. 4) shows that the sites with a high protection status (MPA-MUM and MPA-NTZ) have the highest ecological status (Good and High), whereas the sites with no protection, Natura 2000 sites and not properly managed/enforced MPAs, have a Moderate, Poor or Bad ecological status.

We could imagine that arbitrary choices such as the selection of the considered functional compartments (boxes) and the associated weightings may influence the reef-EBQI. Since boxes encompass the functioning of the whole ecosystem, covering the main trophic functional groups (Fig. 1), it may be considered that the choice of boxes is not arbitrary. We therefore focused on the choice of weightings. In order to check the effect of our choice, we modified the weightings by random changes (e.g. $\pm 1, \pm 2$, with 1000 iterations) for the weighting of each box. These changes did not strongly alter the ecological status of sites: almost all the sites kept the same status; when a change in ecological status was observed, it was not greater than one rank (e.g. Good to High) (Fig. S1 and S2).

\section{Discussion}

We adapted and applied here a method to assess the ecological status of the northwestern Mediterranean algae-dominated rocky reefs, using an ecosystem-based approach, following Personnic et al. (2014) and Rastorgueff et al. (2015). Firstly, we built a conceptual model of the algae-dominated rocky reef ecosystem, based upon the literature with regard to its structure and functioning, taking into account the relevant compartments of this ecosystem. Secondly, we developed a suite of relevant parameters to assess the ecological quality of each compartment and aggregated them into an index, the reef Ecosystem-Based Quality Index (reef-EBQI). This approach has the advantage of combining extensive knowledge of natural history with rigorous analytical metrics - a crucial need for modern ecology (Guidetti et al., 2014).

\subsection{Does the reef-EBQI robustly discriminate between the sites?}

Overall, the sites that obtain a Bad or Poor score are located in areas where the likely stressors can be identified: pollution in the vicinity of a sewage outfall (sites No. 16, 20,21), proximity to a harbour $(15,18,20)$, coastal development $(18,20,27)$, overfishing $(15,18,20,27,30)$, overgrazing $(27,30,38)$. In contrast, the best-scored sites are localized within MPAs with strong and well enforced regulations (NTZ and MUM) (2, 12, 26, 35).

\subsection{Is the reef-EBQI redundant with regard to already existing indices?}

Within the framework of the EU Directives (Habitat Directive, WFD, MSFD), a number of indices based on one or several species have been developed to assess the ecological quality of water bodies and the health status of emblematic species and habitats. As far as algae-dominated rocky reefs are concerned, these indices are mainly and exclusively based on macroalgae, e.g. EEI (Ecological Evaluation Index; Orfanidis et al., 2001, 2003, 2011), CARLIT (CARtografia LIToral; Ballesteros et al., 2007), RSL (Reduced Species List; Wells et al., 2007; Bermejo et al., 2012), CFR (Calidad de Fondos Rocosos; Guinda et al., 2008; Juanes et al., 2008), E-MaQI (Expert-Macrophytes Quality Index; Sfriso et al., 2009), MarMAT (Marine Macroalgae Assessment Tool; Neto et al., 2012), RICQI (Rocky Intertidal Community Quality Index; Díez et al., 2012), ICS (Index of Community Structure; Ar Gall and Le Duff, 2014), QISubMac (Quality Index of Subtidal Macroalgae; Le Gal and DerrienCourtel, 2015), CCO (Cover, Characteristic species, Opportunistic species; Ar Gall et al., 2016). These indices provide a valuable body of 

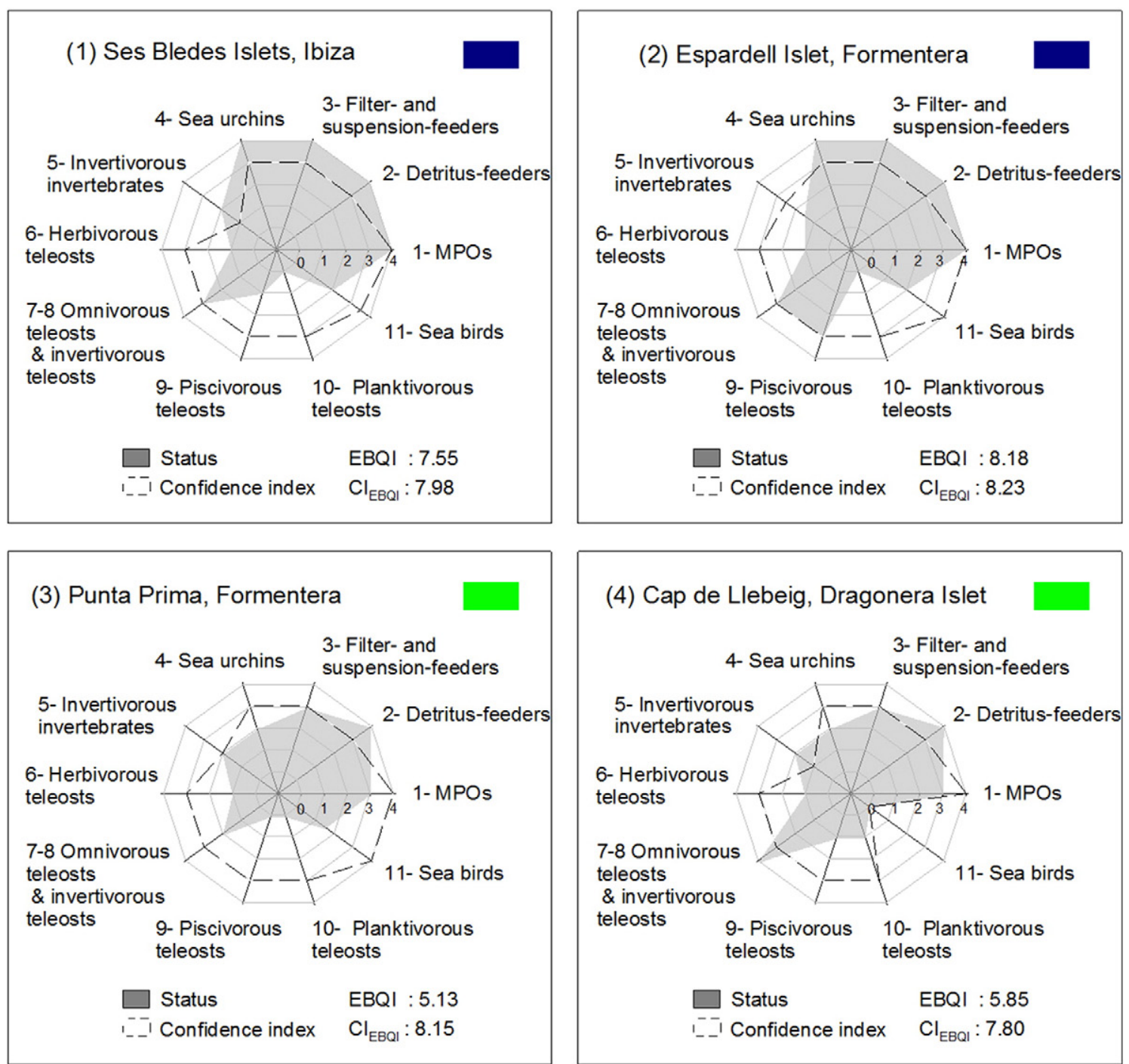

(4) Cap de Llebeig, Dragonera Islet
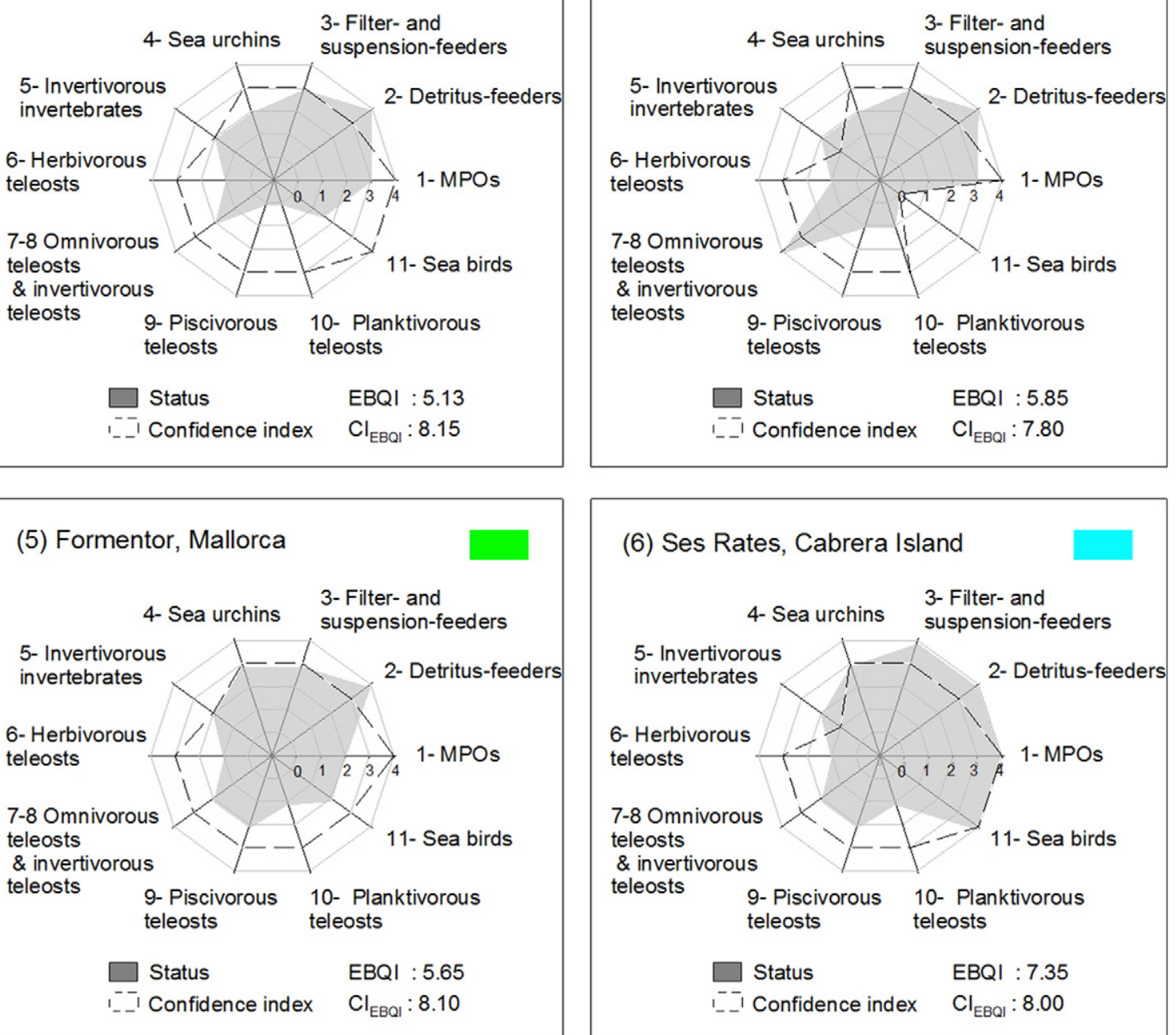

(6) Ses Rates, Cabrera Island

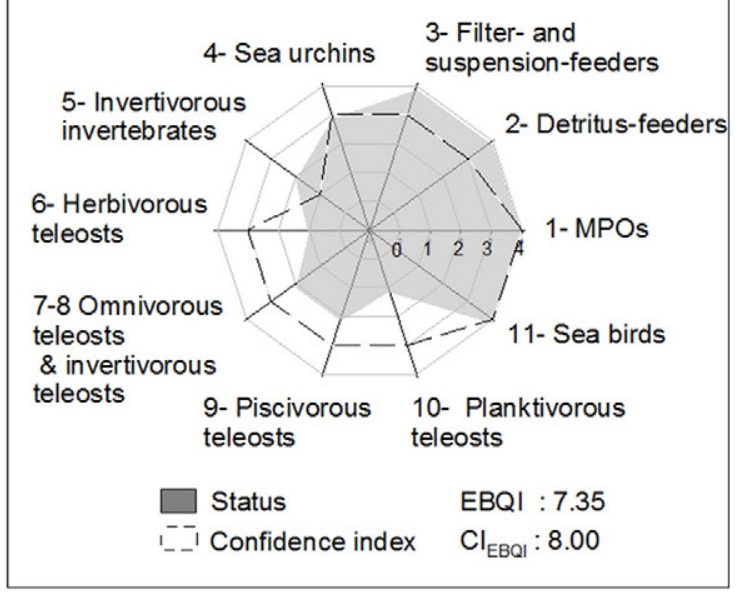

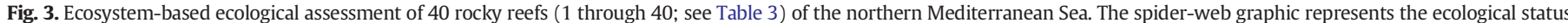

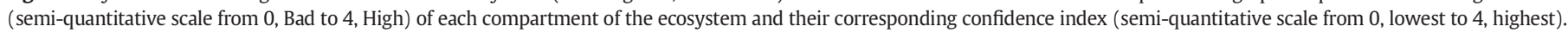
Above right, the coloured box corresponds to ecological status derived from the EBQI: red $=$ Bad, orange $=$ Poor, green $=$ Moderate, light blue $=$ Good and dark blue $=$ High. 


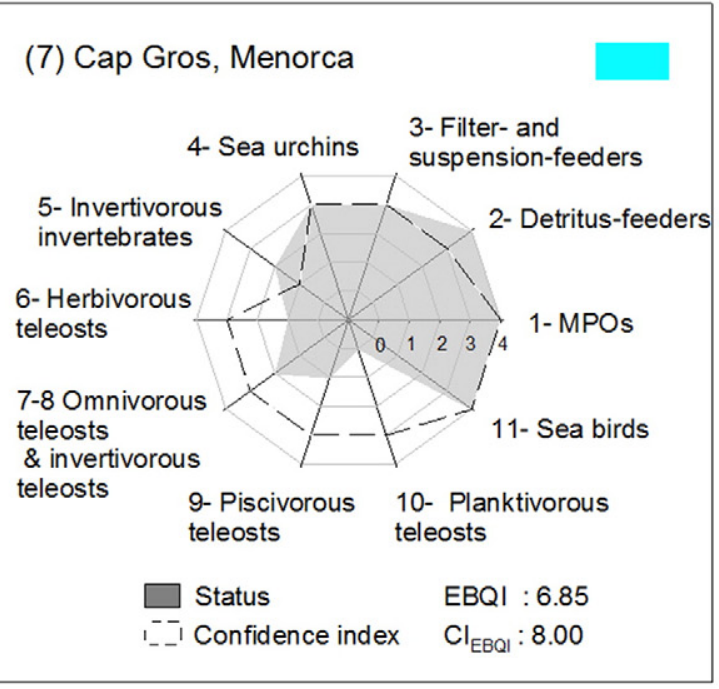

(9) Favàritx, Menorca

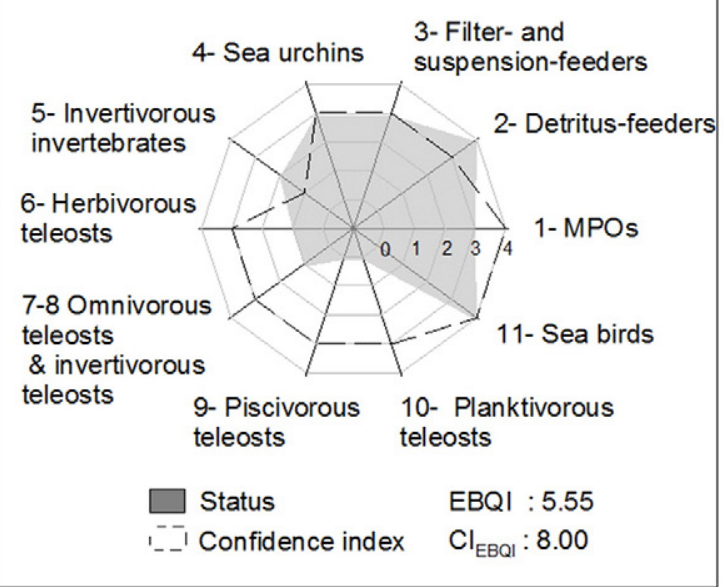

(11) Tossa de Mar

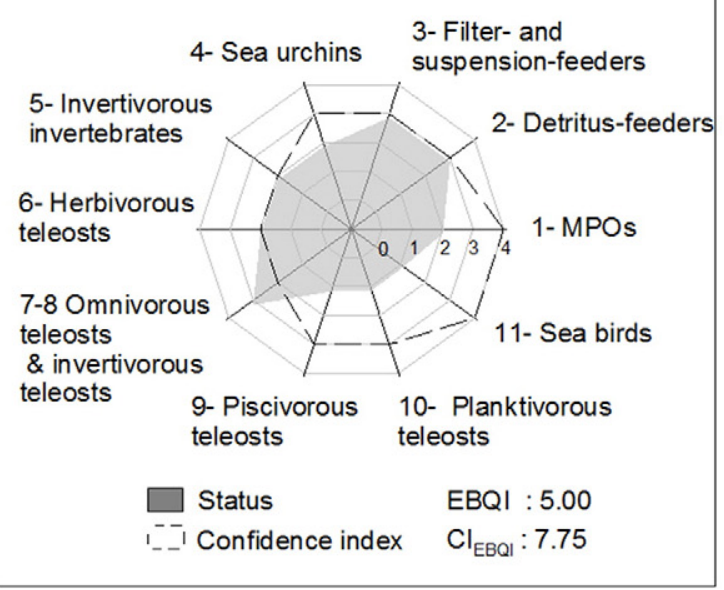

(8) Cavalleria, Menorca

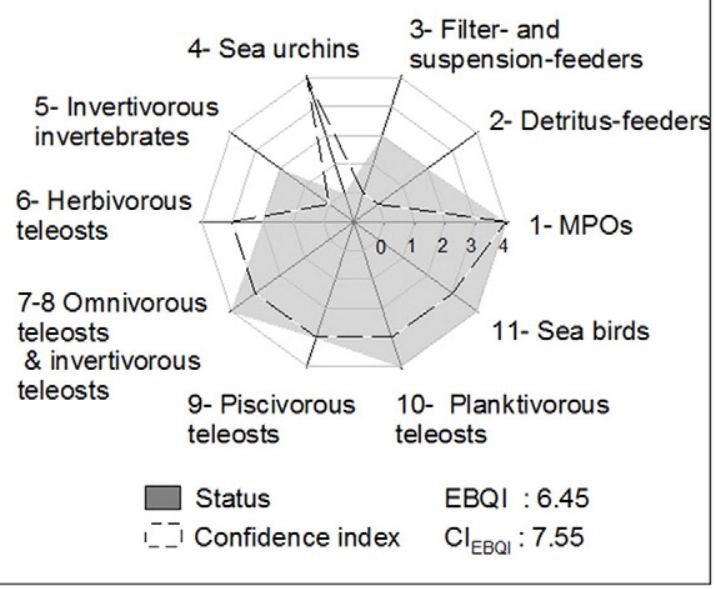

(10) Illa de l'Aire, Menorca

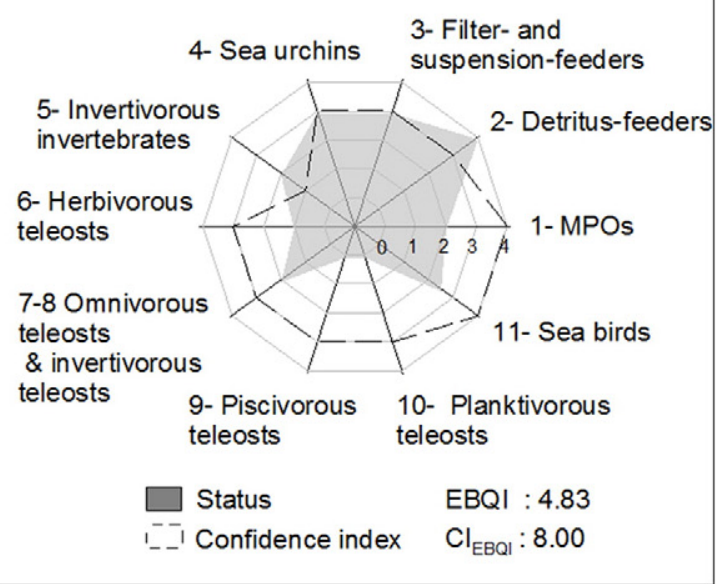

(12) Medes Islands, Estartit

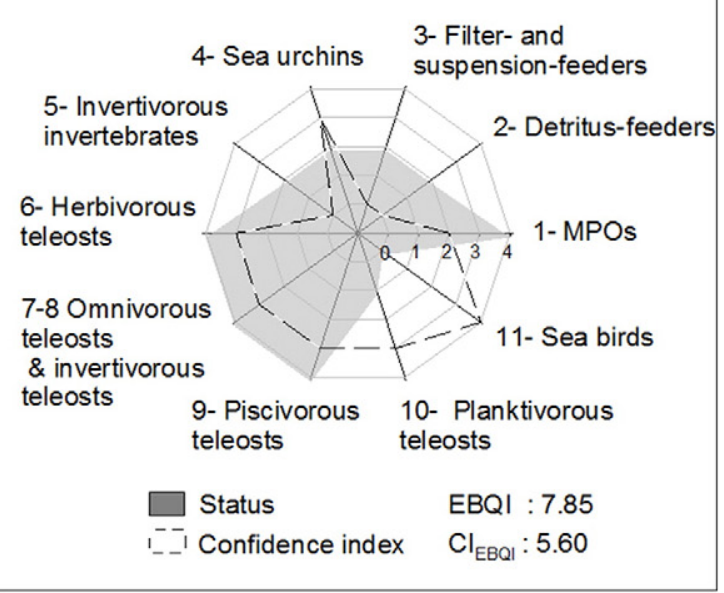

Fig. 3 (continued).

tools to assess the ecological status of a water body. However the good quality of a water body, and the apparent health of some species, including habitat-forming species, is not always indicative of the functioning of the whole ecosystem (Boudouresque et al., 2015a). For example, a site with vast forests of Cystoseira but devoid of fish would be given a high score by the above-mentioned indices, although the lack of fish (especially large predatory fish) reflects the bad functioning of the ecosystem (Sala et al., 2012). In the 


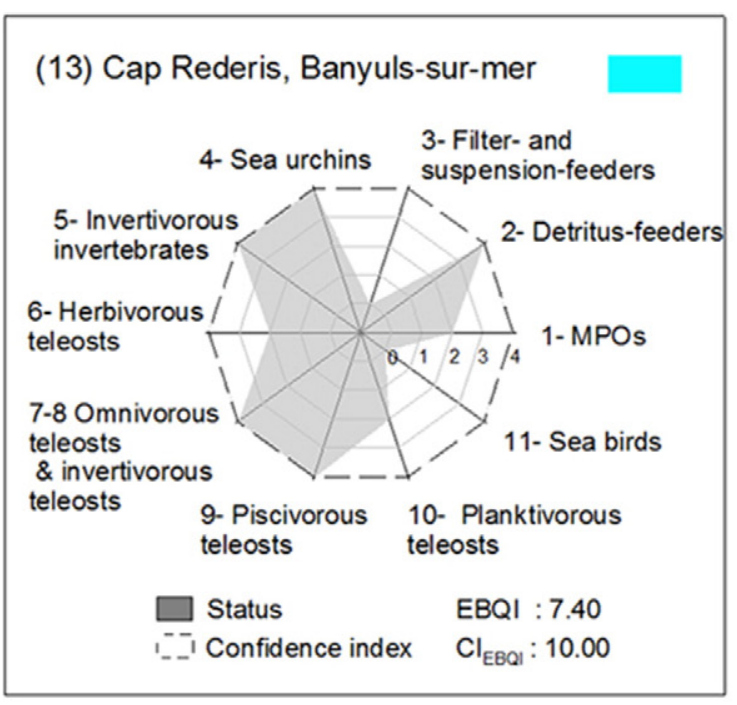

(15) Cap Béar South, Port-Vendres

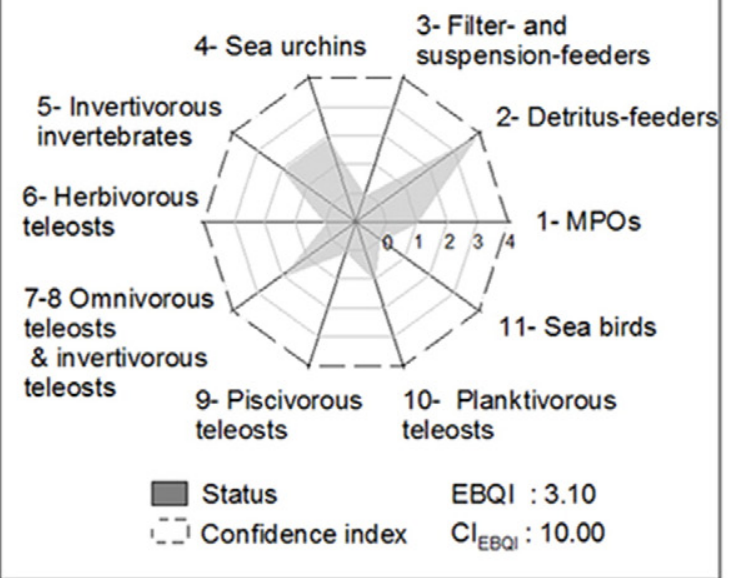

(17) Corbière harbor, Marseille

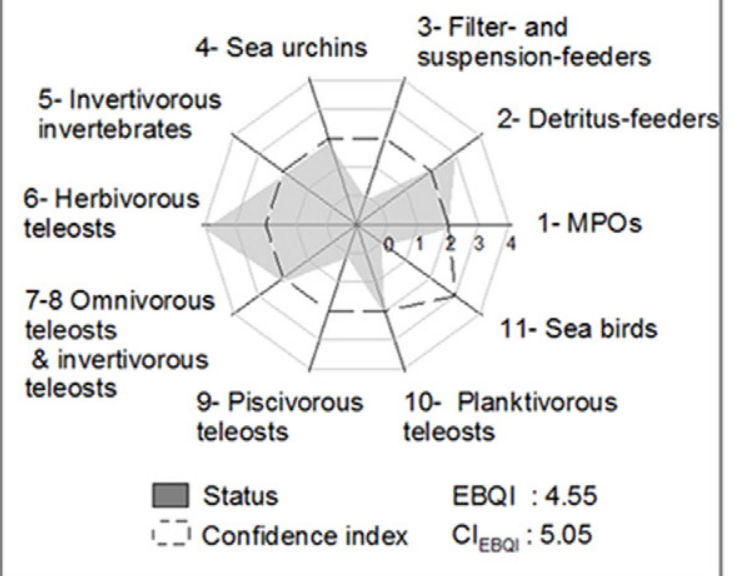

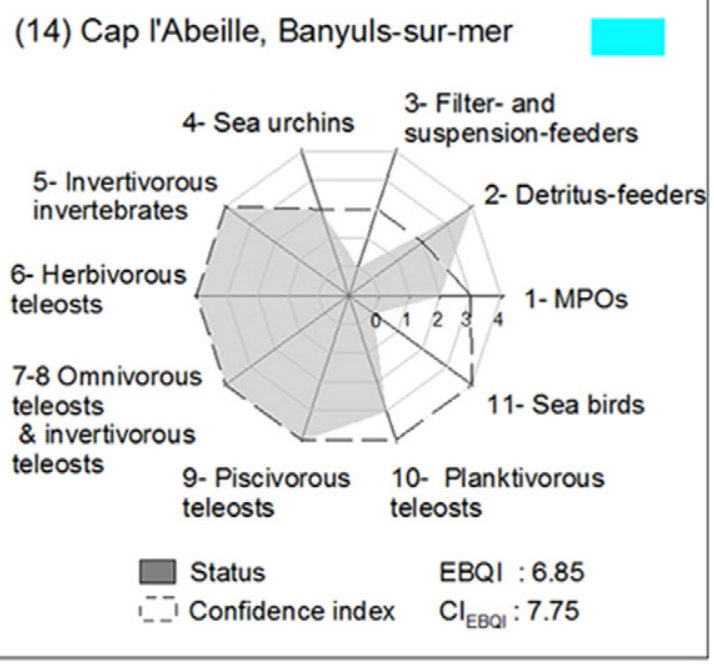

(16) Méjean, Ensuès-la-Redonne

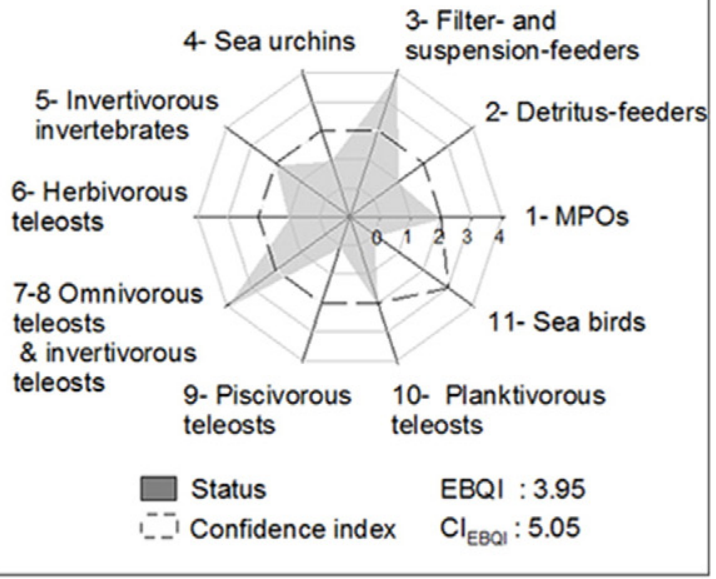

(18) Digue des Catalans, Marseille

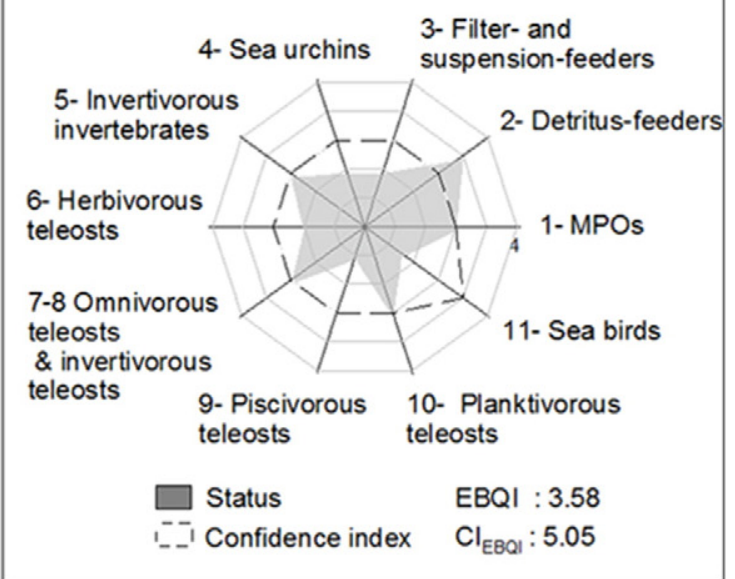

Fig. 3 (continued).

same way, a site with a high density of fish (omnivorous, piscivorous, invertivorous), but exhibiting barren grounds and very poor macroalgal cover (e.g. site No. 38), would be valued by fish specialists, as is usually the case when the effects of protection are assessed (Guidetti et al., 2014), but would get a poor score with the reef-EBQI. 

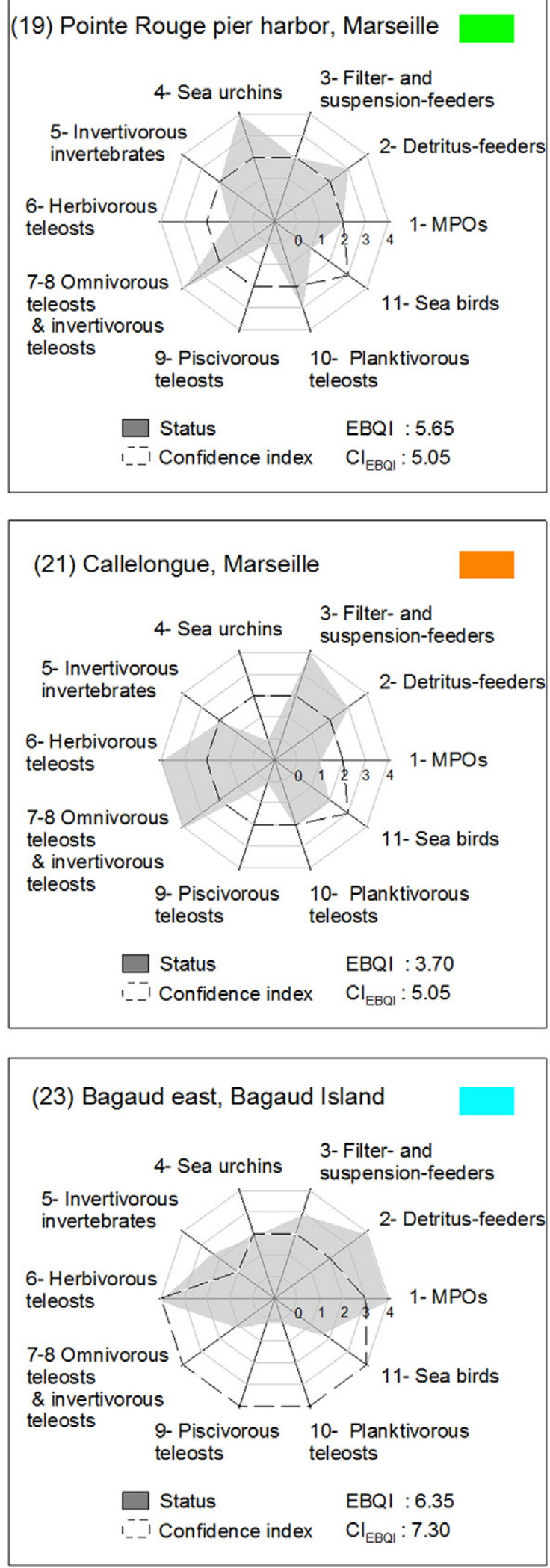

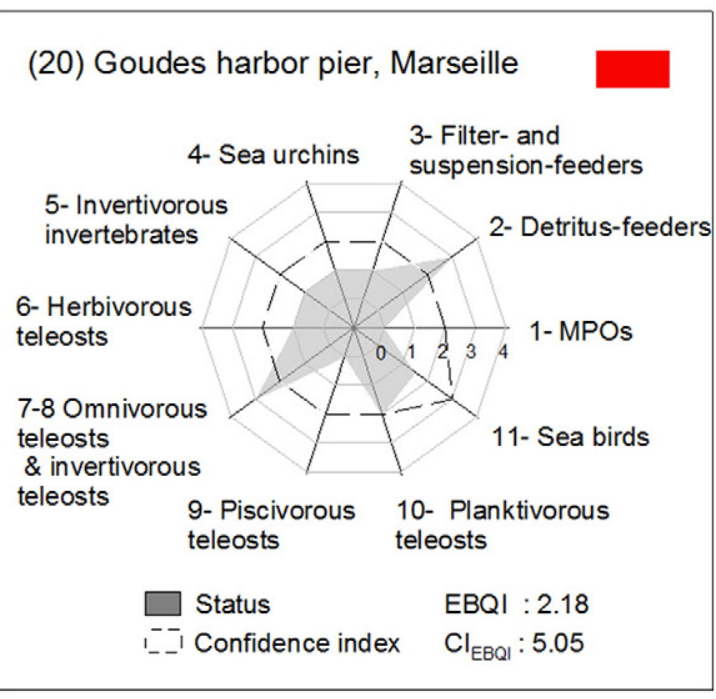

(22) Pointe Montrémian, Bagaud Island

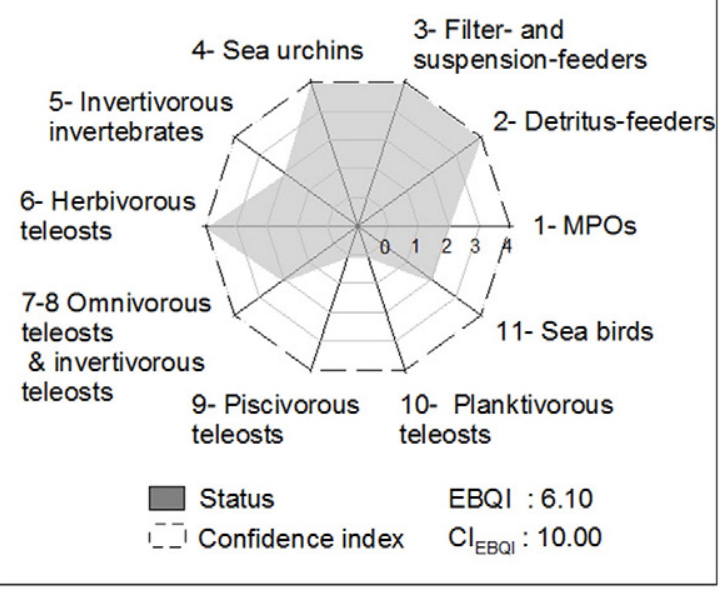

(24) Pointe du Tuff, Port-Cros Island

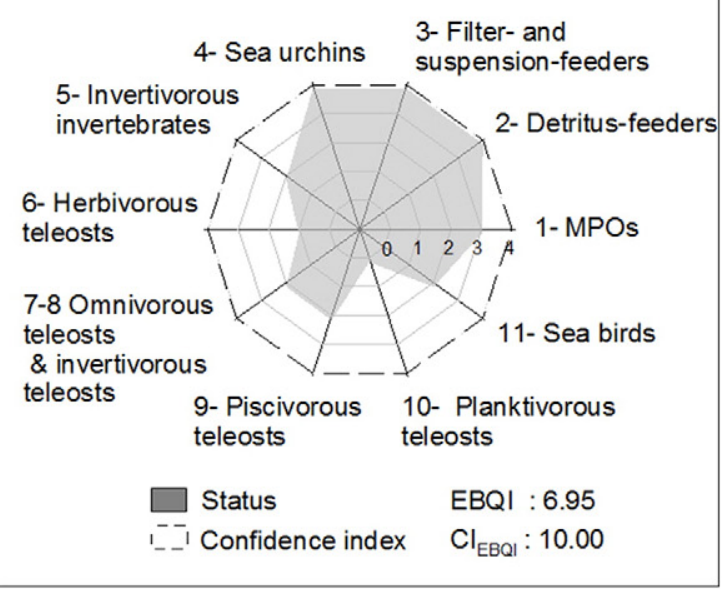

Fig. 3 (continued).

The reef-EBQI is an integrative index that takes into accounts both fish and habitat-forming species, together with several other compartments (e.g. sea urchins, detritus-feeders). This is a highly desirable achievement for the assessment of the whole ecosystem status but may incur the risk of ambiguity. A given value of the index may be due either to abundant fish over a barren ground or to a luxuriant algal forest with almost no fish. The case of Portofino well illustrates the point. Portofino is the only site for which information was available 

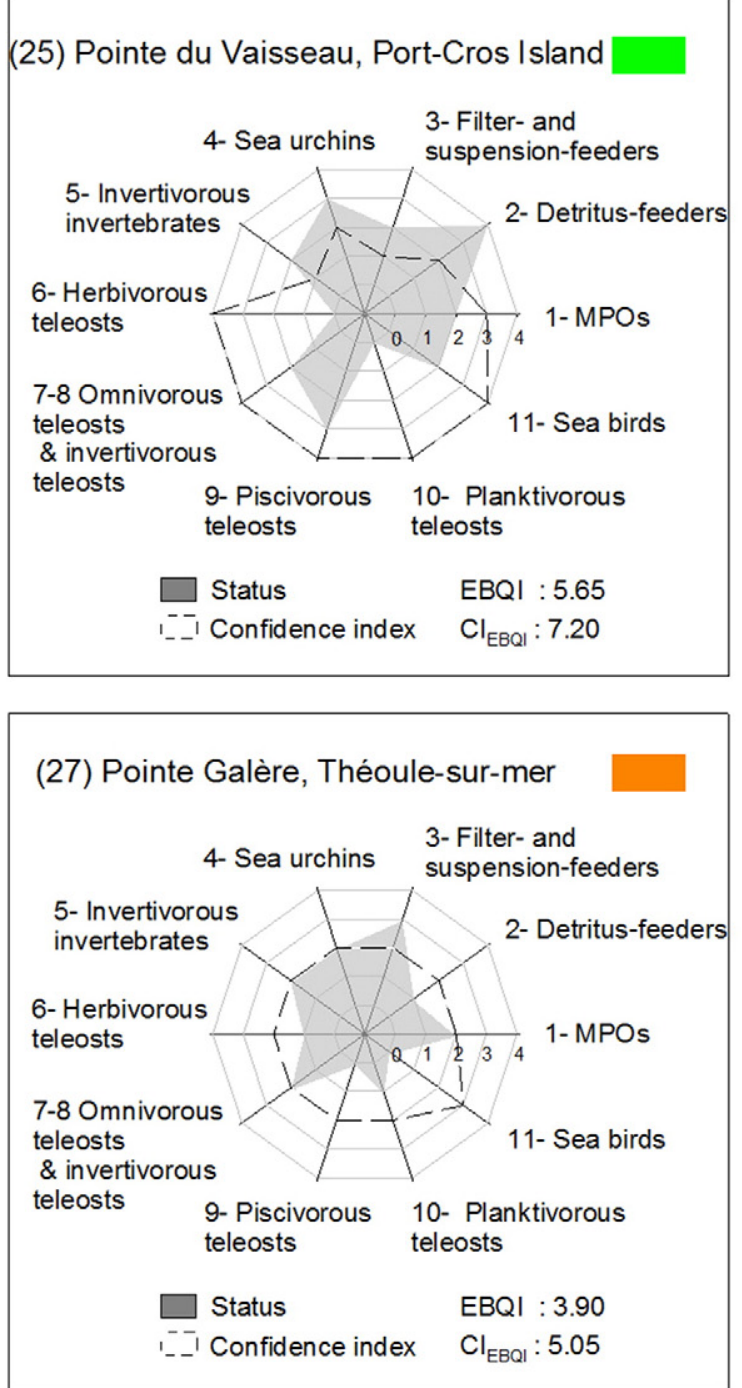

(29) Canto harbor pier, Cannes

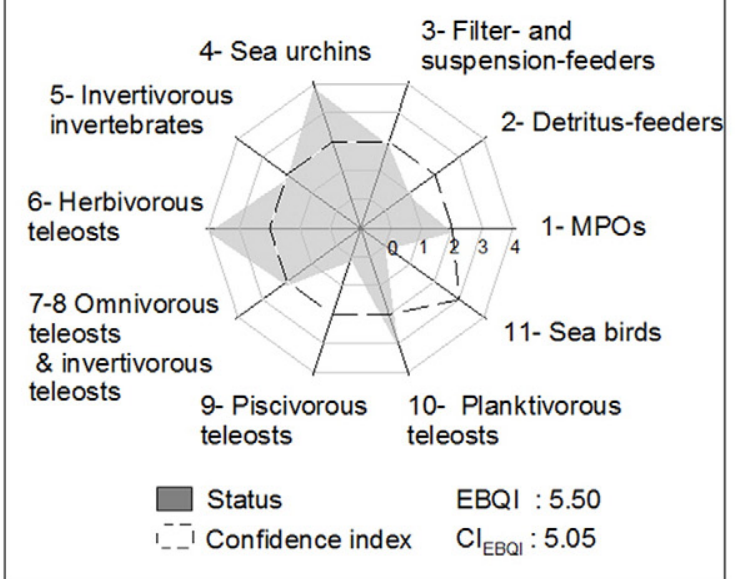

(26) Gabinière Islet, Port-Cros Island

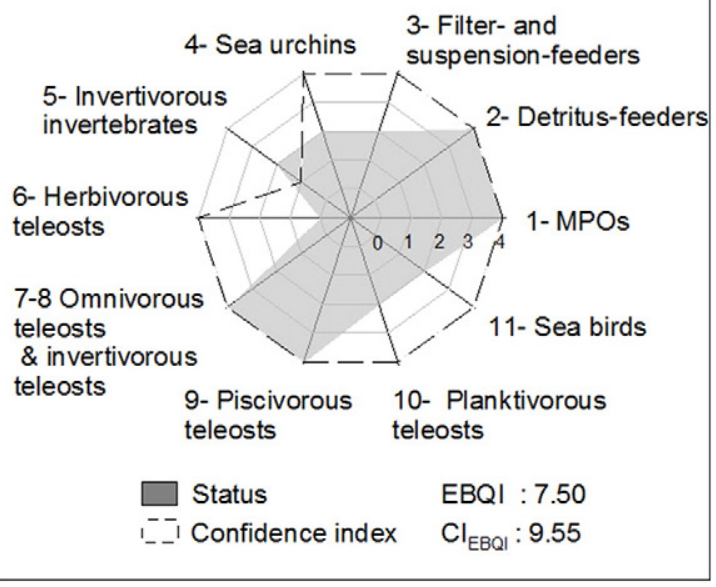

(28) Vieux Port pier, Cannes

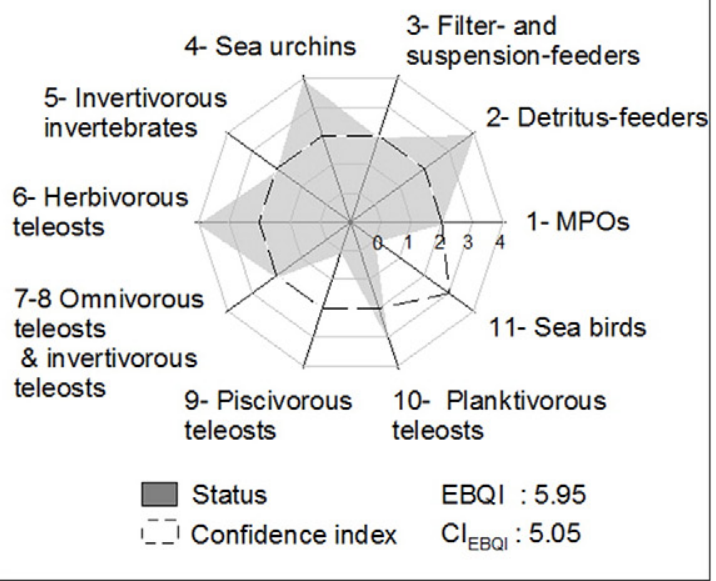

(30) Batéguier, Sainte-Marguerite Island

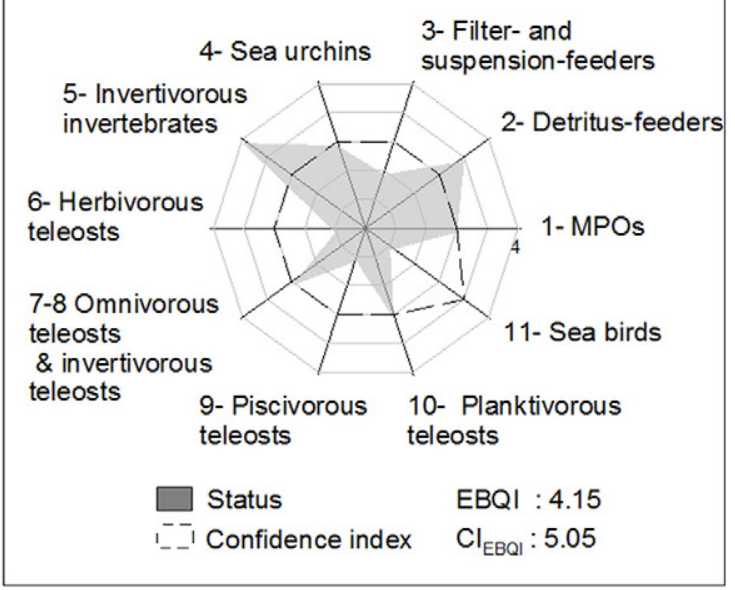

Fig. 3 (continued).

for the periods both before (No. 33; 1990-1993) and after the establishment of the MPA (No. 34; 2008-2014). The ecological status resulted in a rating of Moderate for both periods, with little change in the index value (4.98 in 1990-1993 vs. 5.43 in 2008-2014); in addition, the
Confidence Index was similar (8.30 in 1990-1993 vs. 9.10 in 2008-2014). However, a dramatic decrease of MPOs has occurred, counterbalanced by an increase in fish abundance (Fig. 3). MPA enforcement was therefore effective for the fishes, but did not hamper habitat 


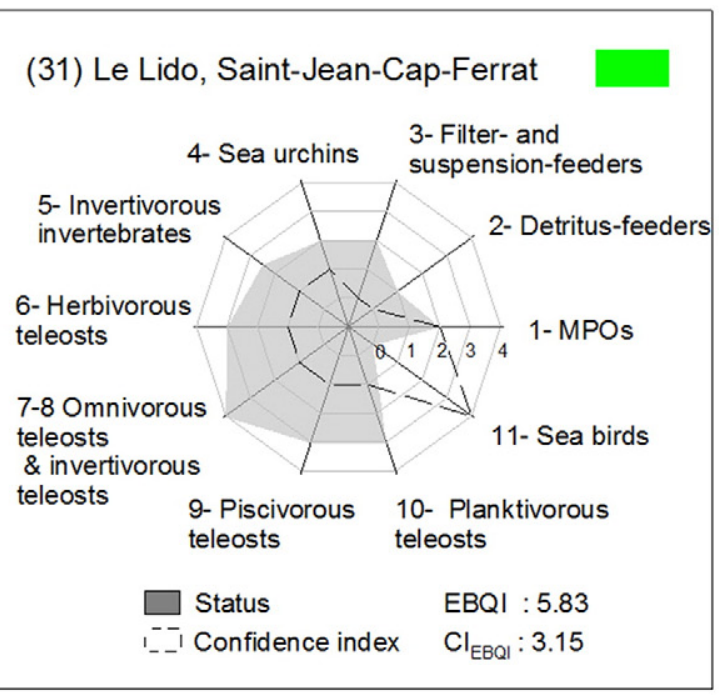

(33) Portofino, Genoa (1990-1993)
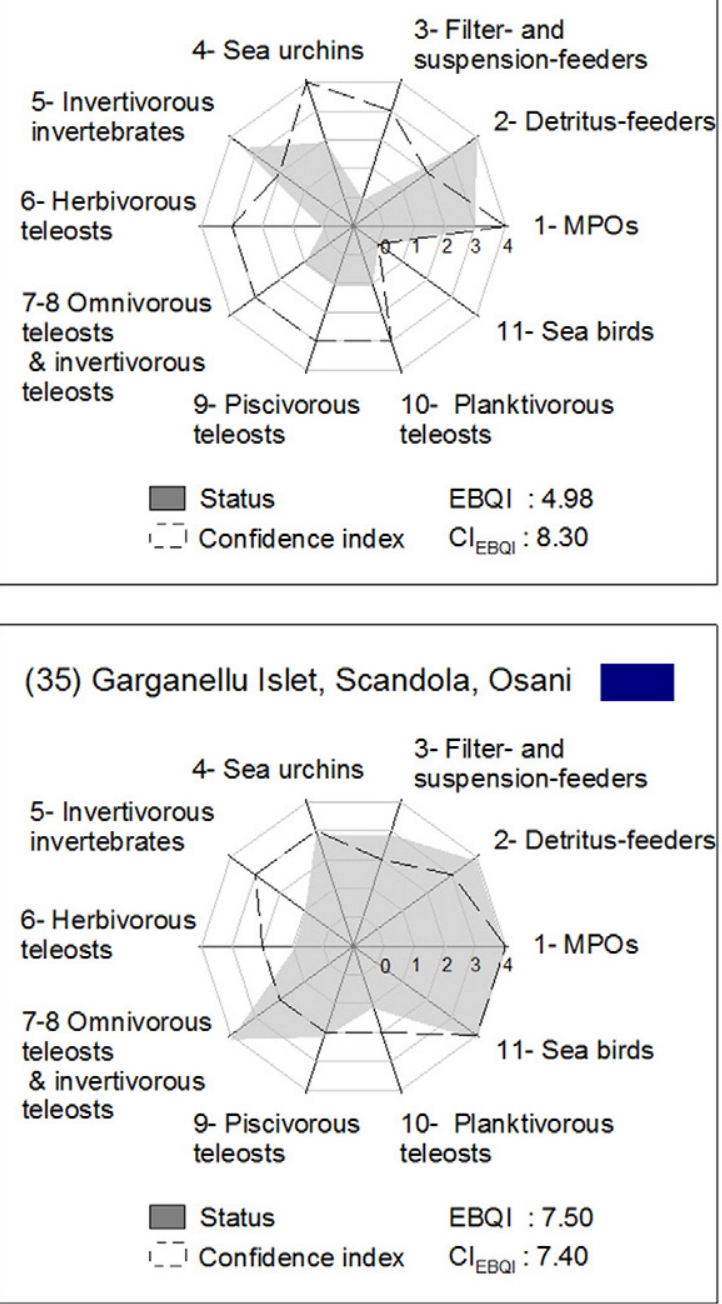

\section{(32) Bergeggi, Savona}

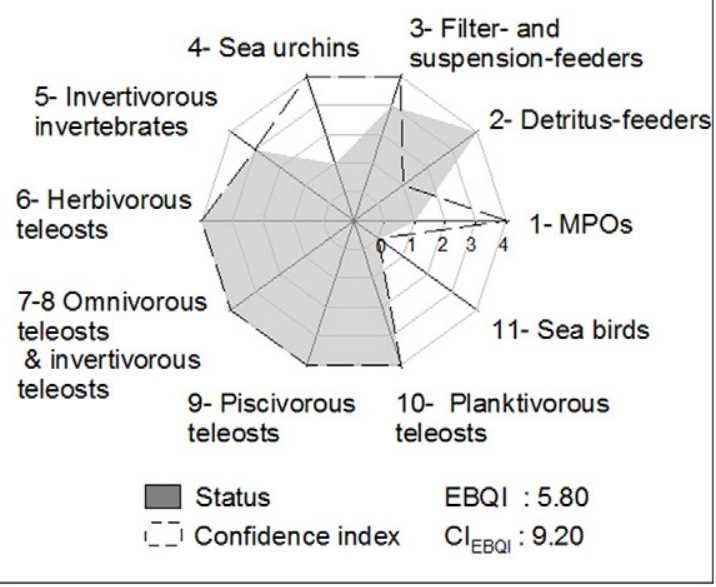

(34) Portofino, Genoa (2008-2014)

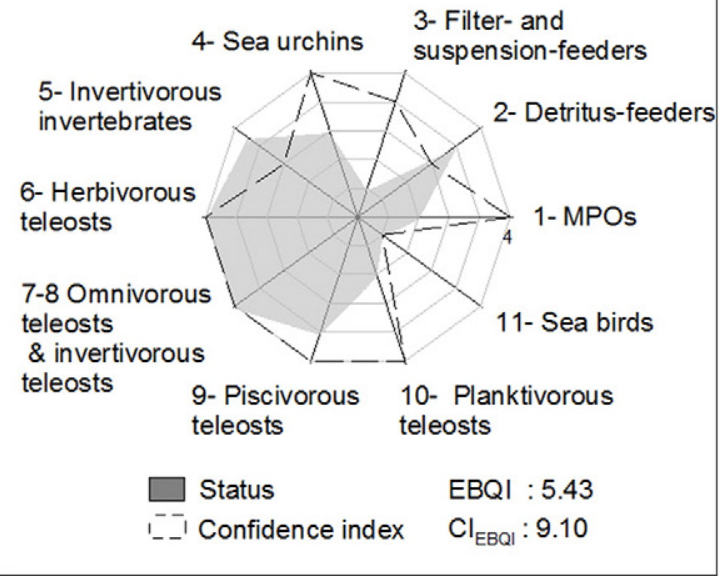

(36) Patrimonio

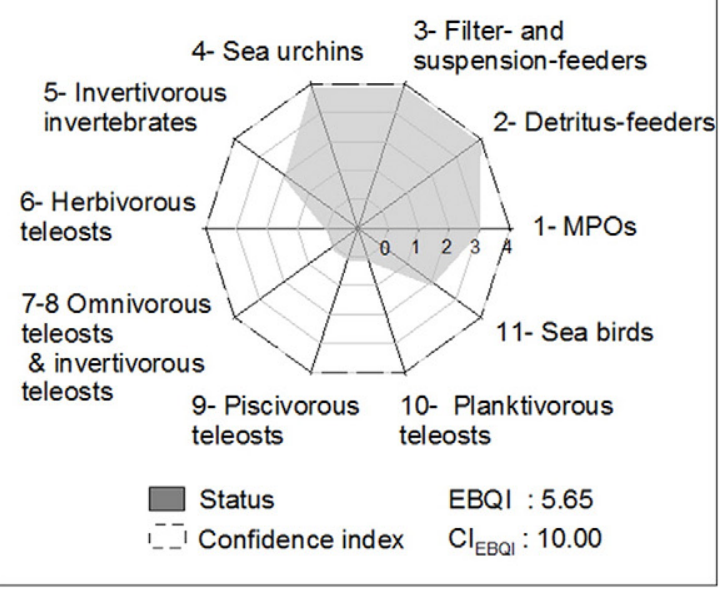

Fig. 3 (continued).

structure degradation (Parravicini et al., 2013). This result is not surprising, as in MPAs, especially within well enforced no-take zones (see Guidetti et al., 2008), fishes respond more clearly and directly to protection measures entailing the reduction of fishing mortality. This highlights the necessity for managers not to take into account just the final score: the scores of the individual components of the index must always be checked in order to see clearly which management actions are required (Gatti et al., 2012, 2015). 

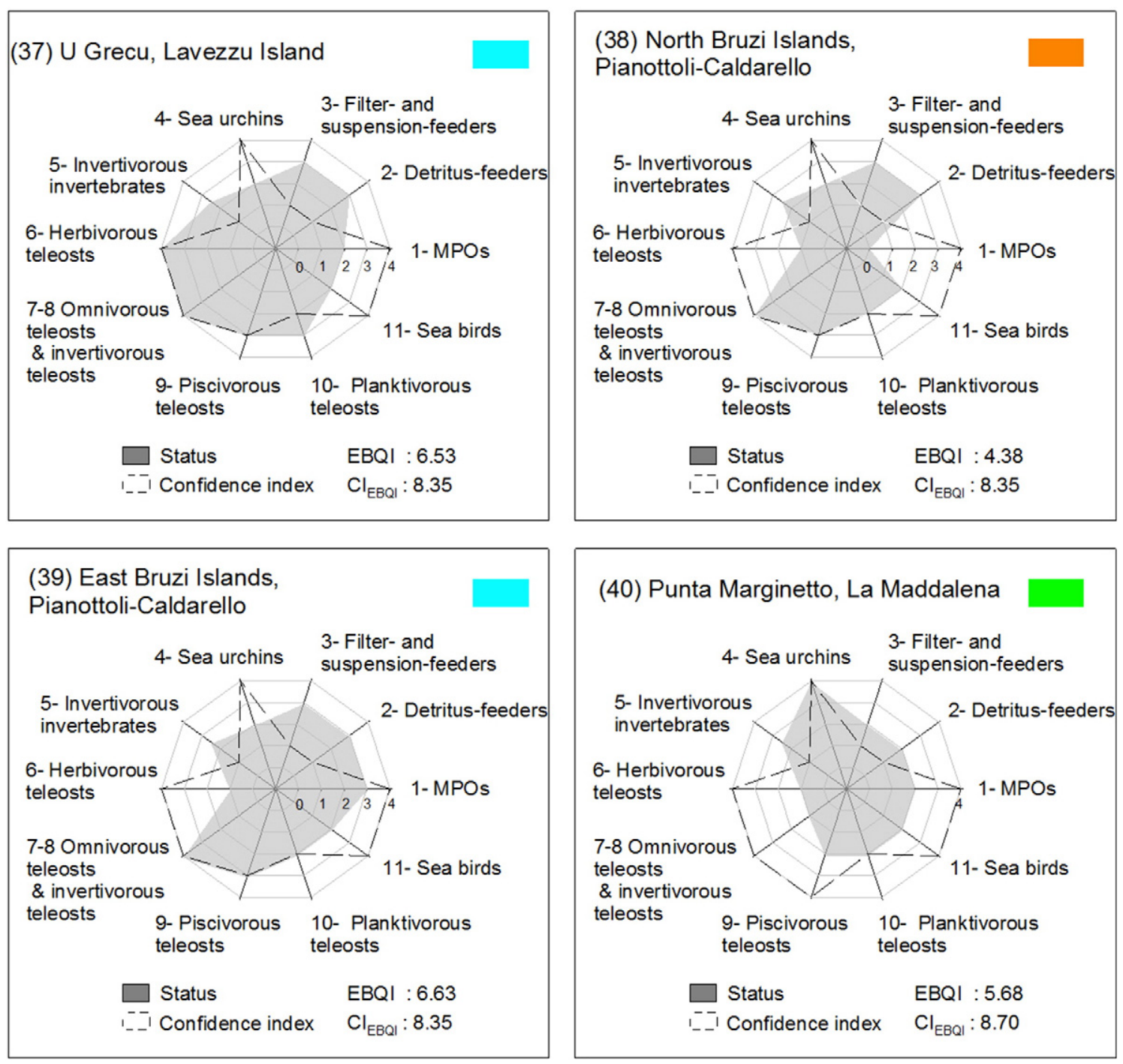

Fig. 3 (continued).

As far as the Mediterranean Sea is concerned, the only indices used are EEI, E-MaQI, RSL and CARLIT. The latter is based upon lower mediolittoral and very shallow ( $<1 \mathrm{~m}$ depth) infralittoral bottom-up controlled habitats, where eutrophication and sea surface disturbances are the main drivers. In contrast, the former indices are based upon fully infralittoral habitats where top-down drivers such as overgrazing and predation also occur. CARLIT data are available for the French coast sites (Table 5); a comparison of CARLIT and reef EBQI from the same sites confirms the absence of any correlation between the two sets of data $(r=0.3, p>0.05)$.

\subsection{Does the protection status of the area matter?}

Our results clearly show that sites without any protection are never associated with Good and High ecological status (Table 4). Among the MPAs, most of the MPA-Natura 2000 sites and those MPAs devoid of NTZ and MUM (i.e. without proper management/enforcement) are mostly associated with Moderate, Poor or Bad ecological status. Only well managed/enforced MPA-NTZ and MPA-MUM are mainly associated with Good and High ecological status (Table 4). The EU Natura 2000 zones, although generally considered as MPAs (Reker et al., 2015), are anything but effectively protected and managed areas (Meinesz and Blanfuné, 2015; Reker et al., 2015). The EU Natura 2000 zones were designated under the Birds Directive and the Habitat
Directive; they targeted a number of vulnerable marine species and habitats, affording them legal recognition and protection. However, they do not include binding management measures, so that, at least in the Mediterranean, the algae-dominated rocky reefs of Natura 2000 areas are often only protected 'on paper', as also evidenced by our findings. In the same way, a number of MPAs, lacking NTZ or MUM areas, are nothing but 'paper parks' (Guidetti et al., 2008; Montefalcone et al., 2009; Sala et al., 2012). It should be noted that the efficiency of MPAs, and especially where NTZ are concerned, also depends, among other factors, upon the date of the implementation of the protection (García-Charton et al., 2008; but see Sala et al., 2012)

Within a well-enforced MPA-NTZ (site No. 38, North Bruzi Islands, Corsica), a paradoxical status was observed. The reef-EBQI was relatively low (4.38; ecological status Poor). The reason lies in the absence of marine forests (Cystoseira brachycarpa), a relatively high density of sea urchins and a high density of fish, corresponding to a barren ground. The persistence of this barren ground, despite the high level of protection, could result from a past disturbance, prior to the establishment of the NTZ, resulting in a regime shift from the forest to the barren ground stage. MPAs can re-establish lost predatory interactions and cause community changes in rocky reefs (Guidetti, 2006). However, the recovery of marine forests can be hindered by the absence of nearby sources of propagules and the slow growth of these species (Sales et al., 2011; Thibaut et al., 2016), which could be the case for the Bruzi Islands 


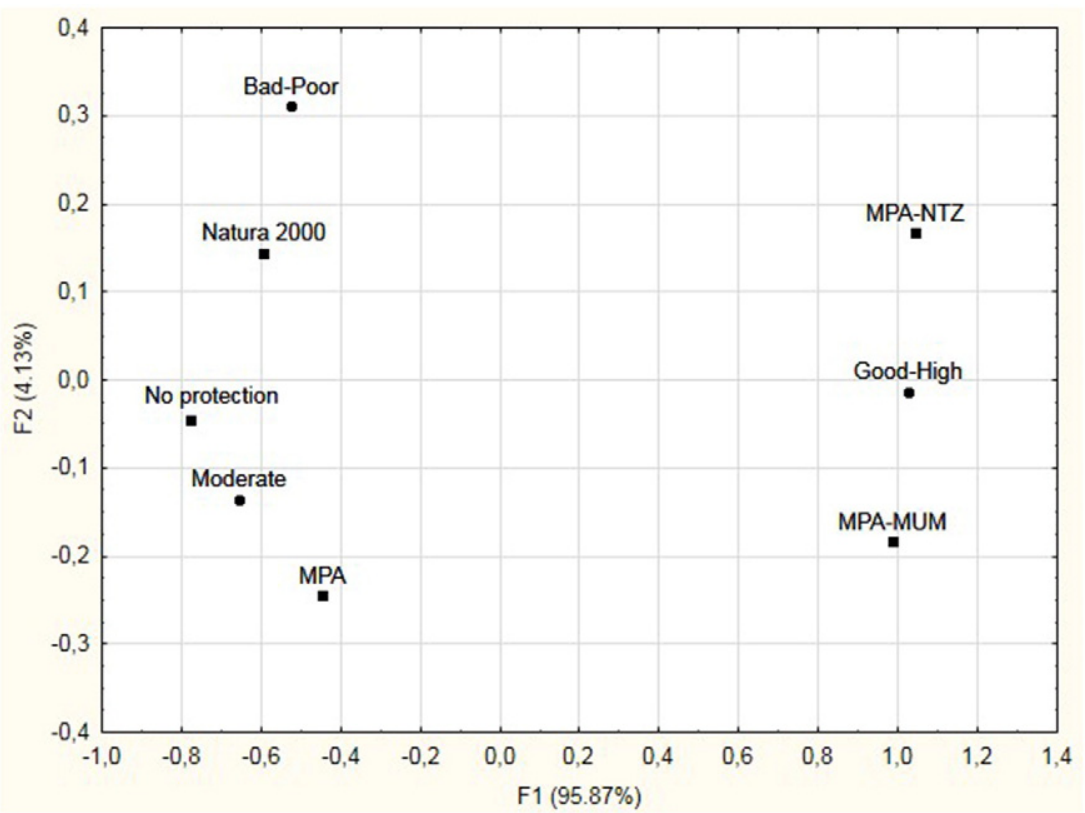

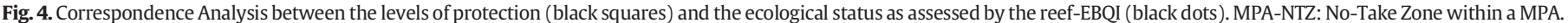
MPA-MUM: Multi-Use Management Zone within a MPA. MPA: neither NTZ nor MPA-MUM.

site. In the Torre Guaceto NTZ MPA (Southern Italy), recovery concerned mainly small bushy species (Guidetti, 2006).

\subsection{Is there an eco-region bias?}

In the NW Mediterranean, the study sites are spread within 2 eco-regions (Bianchi, 2007): Balearic Islands to Corsica and Sardinia (sites No. 1 to 10 and 35 to 40) and Gulf of Lions to Ligurian Sea (sites No. 11 to $34)$. Is the reef-EBQI influenced by regional conditions? As already pointed out by Personnic et al. (2014) for the Posidonia-EBQI, the present study was not designed to address this question, as the sites were chosen according to data availability. However, as far as the algae-dominated rocky reefs are concerned, the available literature does not evidence conspicuous differences between these 2 eco-regions (see references in Section 4.2)

\subsection{Strong and weak points of the reef-EBQI}

Some strong points of the reef-EBQI can be highlighted: (i) it does not require destructive sampling; (ii) its implementation is relatively simple and fast, and therefore inexpensive ( 2 days for 2 divers is enough for the assessment of one site); (iii) it is robust; (iv) it is associated with a Confidence Index, which may indicate the need for the acquisition of more accurate and/or more recent field data, when opportune.

An apparent weak point of the reef-EBQI is that it does not take into account the introduced species, either invasive or habitat transformers (Boudouresque and Verlaque, 2002, 2012). Several species such as Asparagopsis spp., Caulerpa spp. Siganus spp. and Fistularia commersonii can severely impact the algae-dominated rocky reefs in the study area. The major reasons why introduced species were not considered here are: (i) the three already existing EBQIs, namely, the Posidonia oceanica EBQI (Personnic et al., 2014; Boudouresque et al., 2015a), the coralligenous EBQI (Ruitton et al., 2014), and the cave EBQI (Rastorgueff et al., 2015), do not consider them; (ii) invasive species can be considered as a disturbance, in the same way as other disturbances, such as contamination, overfishing and coastal development, and hence they can change the compartments of algae-dominated rocky reefs. They can therefore contribute to explaining or predicting the EBQI values. There is no room in the ecosystem-based doctrine of the EBQI for a mixing of functional parameters with explanatory ones (for the metric of descriptors of biological invasion disturbances, see Section 4.6).

\subsection{Baseline for future prospects}

Identifying the disturbances likely to account for the values of the reef-EBQI was beyond the scope of the present work. However, it is clear that the next step will be to deal with the possible correlation between the EBQI and the putative explanatory variables. Coastal disturbances are often cumulative and have to be linked to the measured parameters and assessed at a fine scale (e.g. Lopez y Royo et al., 2009; Holon et al., 2015; Bermejo et al., 2016; Guarnieri et al., 2016). Spatially explicit approaches able to model the complex relationships between multiple human pressures and coastal ecosystems status have already been successfully applied in the study area (Parravicini et al., 2012).

Coastal habitats are often a mosaic of different ecosystems such as Posidonia oceanica beds, algae-dominated rocky reefs, marine caves and sandy habitats at different depth ranges. No individual index can account for such a diversity of issues: quality of the water body as a whole, status of the ecosystem functioning, natural and human-induced pressures, etc. The future of Integrated Coastal Zone Management (ICZM) therefore does not lie in a unified integrative index, but rather in a combined set of indices, each one providing information regarding a given problem, parameter and/or ecosystem, at a given scale. For instance, the CARLIT index provides information on the ecological status of large water bodies and shallow habitats (Ballesteros et al., 2007), the EBQI Posidonia oceanica assesses the functioning of a pivotal ecosystem resulting from multiple pressures, including overfishing (Personnic et al., 2014; Giakoumi et al., 2015), the MEDOCC index (MEDiterranean OCCidental index) assesses the ecological status of macroinvertebrate assemblages inhabiting soft substrates, in relation to organic pollution (Pinedo et al., 2015, 2016), the ALEX index (ALien Biotic Index) assesses the pressure of biological invasions on hard substrate assemblages (Piazzi et al., 2015), the LIMA index conveys the environmental interest and quality of the seascape formed by the Mediterranean benthos (Gobert et al., 2014), and the OCI (Overall Complexity Index) measures the ecological complexity of coastal marine ecosystems (Paoli et al., 2016). Both managers and scientists are now well aware that looking 
for a single, unified index would be equivalent to hunting the snark (Bond, 2001).

This work is focused on the North-Western Mediterranean Sea. However, the reef-EBQI could easily be used, with minor adjustments, for other Mediterranean regions. For other seas, the same rationale as the one used here could be adopted to build an EBQI adapted to the local ecosystem, choosing different species as proxies for much the same compartments.

\section{Conclusions}

For the first time, a conceptual model of the functioning of algaedominated rocky reefs is proposed. The reef-EBQI index, like previous $\mathrm{EBQI}$ indices, is easy and inexpensive to implement, robust, and not redundant with already existing indices. It is part of an ecological monitoring strategy, both for the ecosystem-based approach for monitoring the coastal zone and for ecosystem-based management, in the framework of the EU MSFD and of the ICZM. Such ecosystem-based approaches successfully complete the approaches based upon individual species and assemblage descriptions. This model provides a tool for assessing the quality of the function of an ecosystem currently under siege in the Mediterranean Sea, with the collapse of most marine forests. Monitoring the ecological state of algae-dominated reef ecosystems and the effects of disturbances over large geographical and temporal scales is made possible with the reef-EBQI. Combined with other EBQIs (e.g. Posidonia-EBQI and cave-EBQI), it provides an integrated view of a marine region, which is essential when addressing questions regarding protection, conservation and restoration.

Supplementary data to this article can be found online at http://dx. doi.org/10.1016/j.marpolbul.2017.01.029.

\section{Competing interests}

The authors have declared that there are no competing interests.

\section{Funding}

This study has been funded by the French Agence de l'Eau RhôneMéditerranée-Corse and the French Agence des Aires Marines Protégées through the French part of the European MSFD project. The funders had no role in the study design, data collection and analysis, decision to publish or drafting of the manuscript.

\section{Acknowledgements}

This study was funded by Agence de l'Eau Rhône Méditerranée \& Corse (CT2014ZEAAMPO) (Pierre Boissery). The authors are indebted to Michael Paul for improvement of the English.

\section{References}

Agnetta, D., Badalamenti, F., Ceccherelli, G., Di Trapani, F., Bonaviri, C., Gianguzza, P., 2015. Role of two co-occurring Mediterranean sea urchins in the formation of barren grounds. Estuar. Coast. Shelf S. 152, 73-77.

Airoldi, L., Beck, M.W., 2007. Loss, status and trends for coastal marine habitats of Europe. Oceanogr. Mar. Biol. Annu. Rev. 45, 345-405.

Airoldi, L., Balata, D., Beck, M.W., 2008. The Gray zone: relationships between habitat loss and marine diversity and their applications in conservation. J. Exp. Mar. Biol. Ecol. $366,8-15$.

Ambrose, R.F., Nelson, B.V., 1983. Predation by Octopus vulgaris in the Mediterranean. Mar. Ecol. 4 (3) (251-161).

Ar Gall, E., Le Duff, M., 2014. Development of a quality index to evaluate the structure of macroalgal communities. Estuar. Coast. Shelf Sci. 139, 99-109.

Ar Gall, E., Le Duff, M., Sauriau, P.G., De Casamajor, M.N., Gevaert, F., Poisson, E. Hacquebart, P.Y., Barillé, A.L., Buchet, R., Bréret, M., Miossec, L., 2016. Implementation of a new index to assess intertidal seaweed communities as bioindicators for the European Water Framework Directory. Ecol. Indic. 60, 162-173.

Ballesteros, E., 1988. Estructura dinámica de la comunidad de Cystoseira mediterranea Sauvageau en el Mediterráneo noroccidental. Investig. Pesq. 53, 313-334.
Ballesteros, E., 1990a. Structure and dynamics of the Cystoseira caespitosa Sauvageau (Fucales, Phaeophyceae) community in the north-western Mediterranean. Sci. Mar. 54, 155-168.

Ballesteros, E., 1990b. Structure and dynamics of the community of Cystoseira zosteroides (Turner) C. Agardh (Fucales, Phaeophyceae) in the northwestern Mediterranean. Sci. Mar. 54, 217-229.

Ballesteros, E., 1993. Species composition and structure of a photophilic algal community dominated by Halopteris scoparia (L.) Sauvageau from the North-Western Mediterranean. Collect. Bot. (Barcelona) 22, 5-24.

Ballesteros, E., Torras, X., Pinedo, S., García, M., Mangialajo, L., de Torres, M., 2007. A new methodology based on littoral community cartography dominated by macroalgae for the implementation of the European Water Framework Directive. Mar. Pollut. Bull. $55,172-180$.

Bellan-Santini, D., 1969. Contribution à l'étude des peuplements infralittoraux sur substrat rocheux (étude qualitative et quantitative de la frange supérieure). Rec. Trav. Stat. Mar. Endoume 47 (63), 1-294.

Bermejo, R., Vergara, J.J., Hernández, I., 2012. Application and reassessment of the reduced species list index for macroalgae to assess the ecological status under the Water Framework Directive in the Atlantic coast of Southern Spain. Ecol. Indic. 12, 46-57.

Bermejo, R., de la Fuente, G., Ramírez-Romero, E., Vergara, J.J., Hernández, I., 2016. Spatia variability and response to anthropogenic pressures of assemblages dominated by a habitat forming seaweed sensitive to pollution (northern coast of Alboran Sea). Mar. Pollut. Bull. 105, 255-264.

Bianchi, C.N., 2007. Biodiversity issues for the forthcoming tropical Mediterranean Sea. Hydrobiologia 580, 7-21.

Bianchi, C.N., Morri, C., Chiantore, M., Montefalcone, M., Parravicini, V., Rovere, A., 2012 Mediterranean Sea biodiversity between the legacy from the past and a future of change. In: Stambler, N. (Ed.), Life in the Mediterranean Sea: A Look at Habitat Changes. Nova Science Publishers, New York, pp. 1-55.

Bianchi, C.N., Corsini-Foka, M., Morri, C., Zenetos, A., 2014. Thirty years after: dramatic change in the coastal marine ecosystems of Kos Island (Greece), 1981-2013. Mediterr. Mar. Sci. 15, 482-497.

Blanco, S., Bécares, E., Cauchie, H.M., Hoffmann, L., Ector, L., 2007. Comparison of biotic indices for water quality diagnosis in the Duero Basin (Spain). Archiv. für Hydrobiol. Supplement. Large Rivers. 17, pp. 267-286.

Blanfuné, A., Boudouresque, C.F., Verlaque, M., Beqiraj, S., Kashta, L., Nasto, I., Ruci, S. Thibaut, T., 2016. Response of rocky shore communities to anthropogenic pressures in Albania (Mediterranean Sea): ecological status assessment through the CARLIT method. Mar. Pollut. Bull. 109, 409-418.

Bonaviri, C., Vega Fernández, T., Badalamenti, F., Gianguzza, P., Di Lorenzo, M., Riggio, S. 2009. Fish versus starfish predation in controlling sea urchin populations in Mediterranean rocky shores. Mar. Ecol. Prog. Ser. 382, 129-138.

Bonaviri, C., Vega Fernández, T., Fanelli, G., Badalamenti, F., Gianguzza, P., 2011. Leading role of the sea urchin Arbacia lixula in maintaining the barren state in southwestern Mediterranean. Mar. Biol. 158, 2505-2513.

Bond, W., 2001. Keystone species - hunting the snark? Science 292, 63-64

Boudouresque, C.F., 1971a. Contribution à l'étude phytosociologique des peuplements algaux des côtes varoises. Vegetatio 22, 83-184.

Boudouresque, C.F., 1971b. Recherches de bionomie analytique, structurale et expérimentale sur les peuplements benthiques sciaphiles de Méditerranée occidentale (fraction algale). La sous-strate sciaphile des peuplements de grandes Cystoseira de mode battu. Bull. Mus. Hist. Nat. Marseille 31, 141-151.

Boudouresque, C.F., 2015. Taxonomy and phylogeny of unicellular eukaryotes. In: Bertrand, J.C., Caumette, P., Lebaron, P., Matheron, R., Normand, P., Sime-Ngando, T. (Eds.), Environmental Microbiology: Fundamentals and Applications. Microbial Ecology. Springer publ., Switzerland, pp. 191-257.

Boudouresque, C.F., Verlaque, M., 2002. Biological pollution in the Mediterranean Sea: invasive versus introduced macrophytes. Mar. Pollut. Bull. 44, 32-38.

Boudouresque, C.F., Verlaque, M., 2012. An overview of species introduction and invasion processes in marine and coastal lagoon habitats. Cah. Biol. Mar. 53, 309-317.

Boudouresque, C.F., Verlaque, M., 2013. Paracentrotus lividus. In: Lawrence, J.M. (Ed.), Sea Urchins: Biology and Ecology, third ed. Elsevier Publ, pp. 97-327.

Boudouresque, C.F., Cadiou, G., Guerin, B., Le Direach, L., Robert, P., 2004. Is there a negative interaction between biodiversity conservation and artisanal fishing in a Marine Protected Area, the Port-Cros National Park (France, Mediterranean Sea)? Sci. Rep. Port-Cros natl. Park 20, 147-160.

Boudouresque, C.F., Personnic, S., Astruch, P., Ballesteros, E., Bellan-Santini, D., Bonhomme, P., Botha, D., Feunteun, E., Harmelin-Vivien, M., Pergent, G., Pastor, J. Poggiale, J.C., Renaud, F., Thibaut, T., Ruitton, S., 2015a. Ecosystem-based versus species-based approach for assessment of the human impact on the Mediterranean seagrass Posidonia oceanica. In: Ceccaldi, H., Hénocque, Y., Koike, Y., Komatsu, T., Stora, G., Tusseau-Vuillemin, M.H. (Eds.), Marine Productivity: Perturbations and Resilience of Socio-ecosystems. Springer Publ, Switzerland, pp. 235-241.

Boudouresque, C.F., Pergent, G., Pergent-Martini, C., Ruitton, S., Thibaut, T., Verlaque, V., 2015b. The necromass of the Posidonia oceanica seagrass meadow: fate, role, ecosystem services and vulnerability. Hydrobiologia http://dx.doi.org/10.1007/s10750-015-2333-y.

Bulleri, F., Benedetti-Cecchi, L., Cinelli, F., 1999. Grazing by the sea urchins Arbacia lixula L and Paracentrotus lividus Lam. in the Northwest Mediterranean. J. Exp. Mar. Biol. Ecol. 241, 81-95.

Cadiou, G., Boudouresque, C.F., Bonhomme, P., Le Diréach, L., 2009. The management of artisanal fishing within the Marine Protected Area of the Port-Cros National Park (northwest Mediterranean Sea): a success story? ICES J. Mar. Sci. 66, 41-49.

Carefoot, T.H., 1987. Aplysia: its biology and ecology. Oceanogr. Mar. Biol. 25, 167-284.

Cariou, N., Chery, A., Jousseaume, M., Richir, J., Lejeune, P., Gobert, S., 2013. L'indice paysager Caulerpa racemosa "ICar". In: Ifremer (Ed.), Proceeding of the Colloque CARHAMB'AR. Ifremer Publ., Brest, pp. 152-157. 
Cefalì, M.E., Cebrian, E., Chappuis, E., Pinedo, S., Terradas, M., Mariani, S., Ballesteros, E. 2016. Life on the boundary: environmental factors as drivers of habitat distribution in the littoral zone. Estuar. Coast. Shelf Sci. 172, 81-92.

Chaix, J.C., 1979. Le cycle biologique et quelques aspects de la reproduction du crabe oxyrhynque Acanthonyx lunulatus (Risso, 1816) (Crustacea Decapoda Oxyrhyncha). Tethys $9,17-22$

Cheminée, A., Sala, E., Pastor, J., Bodilis, P., Thiriet, P., Mangialajo, L., Cottalorda, J.-M., Francour, P., 2013. Nursery value of Cystoseira forests for Mediterranean rocky reef fishes. J. Exp. Mar. Biol. Ecol. 442, 70-79.

Coleman, M.A., Kelaher, B.P., Steinberg, P.D., Millar, A.J., 2008. Absence of a large brown macroalga on urbanized rocky reefs around Sydney, Australia, and evidence for historical decline. J. Phycol. 44, 897-901.

Connell, S.D., Foster, M.S., Airoldi, L., 2014. What are algal turfs? Towards a better description of turfs. Mar. Ecol. Prog. Ser. 495, 299-307.

Cresson, P., Ruitton, S., Ourgaud, M., Harmelin-Vivien, M.L, 2014 Contrasting perception of fish trophic level from stomach content and stable isotope analysis: a Mediterranean artificial reef experience. J. Exp. Mar. Biol. Ecol. 452, 54-62.

Cuadros, A., 2015. Settlement and Post-settlement Processes of Mediterranean Littoral Fishes: Influence of Seascape Attributes and Environmental Conditions at Different Spatial Scales. Ph.D. Thesis. Universidad de las Islas Baleares, Palma de Mallorca.

Dance, C., Savy, S., 1987. Predation on Paracentrotus lividus by Marthasterias glacialis: an in-situ experiment at Port-Cros (France Mediterranean). Posidonia Newsletter 1 , $35-41$.

Dayton, P.K., 1985. Ecology of kelp communities. Annu. Rev. Ecol. Syst. 16, 215-245.

De Burgh, M.E., 1975. Aspects of the Absorption of Dissolved Nutrients by Spines of Paracentrotus lividus (Lamarck). Ph.D. Thesis. University of Dublin, Dublin.

Derrien-Courtel, S., 2008. L'étude des peuplements subtidaux rocheux (flore et faune) du littoral breton permet-elle de contribuer à l'évaluation de la qualité écologique du littoral et d'en mesurer les changements dans le temps? Thèse de l'Ecole doctorale du Muséum "Sciences de la Nature et de l'Homme», Concarneau. 222

Derrien-Courtel, S., Le Gal, A., Grall, J., 2013. Regional-scale analysis of subtidal rocky shore community. Helgol. Mar. Res. 67, 697-712.

Diaz, R., Solan, M., Valente, R., 2004. A review of approaches for classifying benthic habitats and evaluating habitat quality. J. Environ. Manag. 73, 165-181.

Díez, I., Santolaria, A., Gorostiaga, J.M., 2003. Relationships of environmental factors with the structure and distribution of subtidal seaweed vegetation of the western Basque coast (N. Spain). Estuar. Coast. Shelf Sci. 56, 1041-1054.

Díez, I., Bustamante, M., Santolaria, A., Tajadura, J., Muguerza, N., Borja, A., Muxika, I., SaizSalinas, J.I., Gorostiaga, J.M., 2012. Development of a tool for assessing the ecological quality status of intertidal coastal rocky assemblages, within Atlantic Iberian coasts. Ecol. Indic. 12, 58-71.

Estes, J.A., Palmisano, J.F., 1974. Sea otters: their role in structuring nearshore communities. Science 185 (4156), 1058-1060.

Filbee-Dexter, K., Scheibling, R.E., 2014. Sea urchin barrens as alternative stable states of collapsed kelp ecosystems. Mar. Ecol. Prog. Ser. 495, 1-25.

Francour, P., Thibault, J.C., 1995. Le régime alimentaire du balbuzard pêcheur (Pandion haliaetus) dans la Réserve naturelle de Scandola. Trav. Sci. Parc Nat. Rég. Rés. Nat. Corse 53, 11-27.

Francour, P., Thibault, J.C., 1996. The diet of breeding osprey Pandion haliaetus on Corsica: exploitation of a coastal marine environment. Bird Study 43, 129-133.

Francour, P., Harmelin-Vivien, M., Harmelin, J.G., Duclerc, J., 1995. Impact of Caulerpa taxifolia colonization on the littoral ichthyofauna of north-western Mediterranean Sea: preliminary results. Hydrobiologia 300/301, 345-353.

Fraschetti, S., Terlizzi, A., Guarnieri, G., Pizzolante, F., D'Ambrosio, P., Maiorano, P., Beqiraj, S., Boero, F., 2011. Effects of unplanned development on marine biodiversity: a lesson from Albania (central Mediterranean Sea). J. Coast. Res. 58, 106-115.

García-Charton, J.A., Pérez-Ruzafa, A., Marcos, C., Claudet, J., Badalamenti, F., BenedettiCecchi, L., Falcón, J.M., Milazzo, M., Schembri, P.J., Stobart, B., Vandeperre, F., Brito, E., Chemello, R., Dimech, M., Domenici, P., Guala, I., Le Diréach, L., Maggi, E., Planes, S. 2008. Effectiveness of European Atlanto-Mediterranean MPAs: do they accomplish the expected effects on populations, communities and ecosystems? J. Nat. Conserv. 16, 193-221.

Gatti, G., Bianchi, CN Norri, C, Montefalcone, M., Sartoretto, S, 2015. Coralligenous reefs state along anthropized coasts: application and validation of the COARSE index, based on a rapid visual assessment (RVA) approach. Ecol. Indic. 52, 567-576.

Gatti, G., Montefalcone, M., Rovere, A., Parravicini, V., Morri, C., Albertelli, G., Bianchi, C.N., 2012. Seafloor integrity down the harbor waterfront: the coralligenous shoals off Vado Ligure (NW Mediterranean). Adv. Oceanogr. Limnol. 3, 51-67.

Giaccone, G., Alongi, G., Pizzuto, F., Cossu, A., 1994. La vegetazione marina bentonica fotofila del Mediterraneo. II. Infralitorale e circalitorale. Proposte di aggiornamento. Boll. Accad. Gioenia Sci. Nat. 27 (346), 111-157.

Giakoumi, S., Cebrian, E., Kokkoris, G.D., Ballesteros, E., Sala, E., 2012. Relationships between fish, sea urchins and macroalgae: the structure of shallow rocky sublittora communities in the Cyclades, Eastern Mediterranean. Estuar. Coast. Shelf Sci. 109, $1-10$

Giakoumi, S., Halpern, B.S., Michel, L.N., Gobert, S., Sini, M., Boudouresque, C.F., Gambi, M.C., Katsanevakis, S. Lejeune, P. Montefalcone, M., Pergent, G., Pergent-Martini, C. Sanchez-Jerez, P., Velimirov, B., Vizzini, S., Abadie, A., Coll, M., Guidetti, P., Micheli, F., Possingham, H.P., 2015. Towards a framework for assessment and management of cumulative human impacts on marine food webs. Conserv. Biol. 29, 1228-1234.

Gianguzza, P., Agnetta, D., Bonaviri, C., Di Trapani, F., Visconti, G., Gianguzza, F., Riggio, S 2011. The rise of thermophilic sea urchins and the expansion of barren grounds in the Mediterranean Sea. Chem. Ecol. 27, 129-134.

Gobert, S., Chéry, A., Volpon, A., Pelaprat, C., Lejeune, P., 2014. The seascape as an indicato of environmental interest and quality of the Mediterranean benthos: the in situ development of a description index: the LIMA. In: Musard, O., et al. (Eds.), Underwater Seascapes. Springer International Publishing, Switzerland, pp. 277-291.

Guarnieri, G., Bevilacqua, S., De Leo, F., Farella, G., Maffia, A., Terlizzi, A., Fraschetti, S., 2016. The challenge of planning conservation strategies in threatened seascapes: understanding the role of fine scale assessments of community response to cumulative human pressures. PLoS ONE 11 (2), e0149253.

Guidetti, P., 2004. Consumers of sea urchins, Paracentrotus lividus and Arbacia lixula, in shallow Mediterranean rocky reefs. Helgol. Mar. Res. 58, 110-116.

Guidetti, P., 2006. Marine reserves reestablish lost predatory interactions and cause community changes in rocky reefs. Ecol. Appl. 16, 963-976.

Guidetti, P., Dulčić, J., 2007. Relationships among predatory fish, sea urchins and barrens in Mediterranean rocky reefs across a latitudinal gradient. Mar. Environ. Res. 63, 168-184.

Guidetti, P., Milazzo, M., Bussotti, S., Molinari, A., Murenu, M., Pais, A., Spano, N., Balzano, R., Agardy, T., Boero, F., Carrada, G., Cattaneo-Vietti, R., Cau, A., Chemello, R., Greco, S., Mangarano, A., Notarbartolo di Sciara, G., Fulvio Russo, G., Tunesi, L., 2008. Italian marine reserve effectiveness: does enforcement matter? Biol. Conserv. 141, 699-709.

Guidetti, P., Parravicini, V., Morri, C., Bianchi, C.N., 2014. Against nature? Why ecologists should not diverge from natural history. Vie Milieu - Life Environ. 64, 1-8.

Guinda, X., Juanes, J.A., Puente, A., Revilla, J.A., 2008. Comparison of two methods for quality assessment of macroalgae assemblages, under different pollution types. Ecol. Indic. 8, 743-753.

Guyot, I., 1990. Le cormoran huppé de Corse: biologie et interactions avec la pêche professionnelle. Trav. Sci. Parc Nat. Rég. Rés. Nat. Corse 28, 1-40.

Habitats Directive, 1992. Council Directive 92/43/EEC of 21 May 1992 on the conservation of natural habitats and of wild fauna and flora. Off. J. Eur. Union L206, 7-50 22 July 1992

Halpern, B.S., Walbridge, S., Selkoe, K.A., Kappel, C.V., Micheli, F., D'Agrosa, C., Bruno, J.F., Casey, K.S., Ebert, C., Fox, H.E., Fujita, R., Heinemann, D., Lenihan, H.S., Madin, E.M.P., Perry, M.T., Selig, E.R., Spalding, M., Steneck, R., Watson, R., 2008. A global map of human impact on marine ecosystems. Science 319, 948-952.

Harley, C.D., Anderson, K.M., Demes, K.W., Jorve, J.P., Kordas, R.L., Coyle, T.A., Graham, M.H., 2012. Effects of climate change on global seaweed communities. J. Phycol. 48, 1064-1078.

Harmelin-Vivien, M., Francour, P., 1992. Trawling or visual censuses? Methodological bias in the assessment of fish populations in seagrass beds. PSZN I Mar. Ecol 13, 41-51.

Harmelin-Vivien, M.L., Harmelin, J.G., Chauvet, C., Duval, C., Galzin, R., Lejeune, P., Barnabe, G., Blanc, F., Chevalier, R., Duclerc, J., Lasserre, G., 1985. Evaluation visuelle des peuplements et populations de poissons: méthodes et problèmes. Rev. Ecol. (Terre Vie) 40, 467-540.

Hawkins, S.J., Moore, P.J., Burrows, M.T., Poloczanska, E., Mieszkowska, N., Herbert, R.J., Jenkins, S.R, Thompson, R.C., Genner, M.J., Southward, A.J., 2008. Complex interactions in a rapidly changing world: responses of rocky shore communities to recent climate change. Clim. Res. 37, 123-133.

Helmuth, B., Mieszkowska, N., Moore, P., Hawkins, S.J., 2006. Living on the edge of two changing worlds: forecasting the responses of rocky intertidal ecosystems to climate change. Annu. Rev. Ecol. Evol. Syst. 37, 373-404.

Hereu, B., Zabala, M., Linares, C., Sala, E., 2005. The effects of predator abundance and habitat structural complexity on survival of juvenile sea urchins. Mar. Biol. 146, 293-299.

Hereu, B., Zabala, M., Sala, E., 2008. Multiple controls of community structure and dynamics in a sublittoral marine environment. Ecology 89, 3423-3435.

Hereu, B., Linares, C., Sala, E., Garrabou, J., Garcia-Rubies, A., Diaz, D., Zabala, M., 2012. Multiple processes regulate long-term population dynamics of sea urchins on Mediterranean rocky reefs. PLoS One 7 (5), e36901.

Hereu Fina, B., 2004. The Role of Trophic Interactions Between Fishes, Sea Urchins and Algae in the Northwestern Mediterranean Rocky Infralittoral. Tesi Doctoral. Univ. Barcelona, Barcelona.

Hoare, J.M., Monks, A., O'Donnel, C.F.J., 2013. Do population indicators work? Investigating correlated responses of bird populations in relation to predator management. Ecol. Indic. 25, 23-34

Holon, F., Mouquet, N., Boissery, P., Bouchoucha, M., Delaruelle, G., Tribot, A.S., Deter, J., 2015. Fine-scale cartography of human impacts along French Mediterranean coasts: a relevant map for the management of marine ecosystems. PLoS ONE 10 (8), e0135473.

Jones, C.G., Lawton, J.H., Shachak, M., 1994. Organisms as ecosystem engineers. Oikos 69, 373-386.

Juanes, J.A., Guinda, X., Puente, A., Revilla, J.A., 2008. Macroalgae, a suitable indicator of the ecological status of coastal rocky communities in the NE Atlantic. Ecol. Indic. 8, 351-359.

Khoury, C., 1987. Ichtyofaune des herbiers de posidonies du Parc national de Port-Cros: composition, éthologie alimentaire et rôle dans le réseau trophique. Doctoral Thesis. Aix-Marseille II University, Marseille.

Lamela-Silvarrey, C., Fernández, C., Anadón, R., Arrontes, J., 2012. Fucoid assemblages on the north coast of Spain: past and present (1977-2007). Bot. Mar. 55, 199-207.

Ledoyer, M., 1966. Ecologie de la faune vagile des biotopes méditerranéens accessibles en scaphandre autonome. I. Introduction: données analytiques sur les biotopes de substrat dur. Rec. Trav. Stat Mar. Endoume 40 (56), 103-149.

Le Gal, A., Derrien-Courtel, S., 2015. Quality Index of Subtidal Macroalgae (QISubMac): a suitable tool for ecological quality status assessment under the scope of the European Water Framework Directive. Mar. Pollut. Bull. 101, 334-348.

Ling, S.D., Scheibling, R.E., Rassweiler, A., Johnson, C.R., Shears, N., Connell, S.D., Salomon, A.K., Nordehaug, K.M., Péres-Matus, A., Hernández, J.C., Clemente, S., Blamey, L.K., Hereu, B., Ballesteros, E., Sala, E., Garrabou, J., Cebrian, E., Zabala, M., Fujita, A.D., Johnson, L.E., 2015. Global regime shift of catastrophic sea urchin overgrazing. Philos. Trans. R. Soc. B 370 (20130269). 
Littler, M.M., Littler, D.S., 1980. The evolution of thallus from and survival strategies in benthic marine macroalgae: field and laboratory tests of a functional form model. Am. Nat. 116 (1), 25-44.

Lopez y Royo, C.L., Silvestri, C., Pergent, G., Casazza, G., 2009. Assessing human-induced pressures on coastal areas with publicly available data. J. Environ. Manag. 90, 1494-1501.

Martínez-Crego, B., Alcoverro, T., Romero, J., 2010. Biotic indices for assessing the status of coastal waters: a review of strengths and weaknesses. J. Environ. Monit. 12 1013-1028.

Meinesz, A., 1979. Contribution à l'étude de Caulerpa prolifera (Forsskål) Lamouroux (Chlorophycée - Caulerpale). I. Morphogénèse et croissance dans une station des côtes continentales françaises de la Méditerranée. Bot. Mar. 27, 27-39.

Meinesz, A., Blanfuné, A., 2015. 1983-2013: development of marine protected areas along the French Mediterranean coasts and perspectives for achievement of the Aichi target. Mar. Policy 54, 10-16.

Micheli, F., Benedetti-Cecchi, L., Gambaccini, S., Bertocci, I., Borsini, C., Osio, G.C., Romano, F., 2005. Cascading human impacts, marine protected areas, and the structure of Mediterranean reef assemblages. Ecol. Monogr. 75, 81-102.

Montefalcone, M., Albertelli, G., Morri, C., Parravicini, V., Bianchi, C.N., 2009. Legal protection is not enough: Posidonia oceanica meadows in marine protected areas are not healthier than those in unprotected areas of the northwest Mediterranean Sea. Mar. Pollut. Bull. 58, 515-519.

Morat, F., 2007. Régime alimentaire de la population de cormoran huppé de Méditerranée (Phalacrocorax aristotelis desmarestii) de Riou. Marseille CEEP and Centre d'Océanologie de Marseille ed., Marseille.

Morat, F., Mante, A., Drunat, E., Dabat, J., Bonhomme, P., Harmelin-Vivien, M., Letourneur Y., 2011. Diet of the Mediterranean European shag, Phalacrocorax aristotelis desmarestii, its ecological significance and interaction with local fisheries in the Riou Archipelago (Marseilles, France). Vie Milieu. 61, pp. 77-86.

Morton, B., Peharda, M., Harper, E.M., 2007. Drilling and chipping patterns of bivalve prey predation by Hexaplex trunculus (Mollusca: Gastropoda: Muricidae). J. Mar. Biol. Assoc. UK 87, 933-940

MSFD, 2008/56/EC, European parliament and the council of the European Union, 2008f. Commission Decision of 17 June 2008 establishing a framework for community action in the field of marine environmental policy, Marine Strategy Framework Directive. Off. J. Eur. Union L164, 19-40 25 June 2008.

Nédelec, H., 1982. Ethologie alimentaire de Paracentrotus lividus dans la baie de Galeria (Corse) et son impact sur les peuplements phytobenthiques. Thèse Doct. $3^{\circ}$ cycle Océanol. Biol. Univ. Paris VI, Paris.

Neto, J.M., Gaspar, R., Pereira, L., Marques, J.C., 2012. Marine Macroalgae Assessment Tool (MarMAT) for intertidal rocky shores. Quality assessment under the scope of the European Water Framework Directive. Ecol. Indic. 19, 39-47.

Orfanidis, S., Panayotidis, P., Stamatis, N., 2001. Ecological evaluation of transitional and coastal waters: a marine benthic macrophytes-based model. Mediterr. Mar. Sci. 2. 45-65.

Orfanidis, S., Panayotidis, P., Stamatis, N., 2003. An insight to the ecological evaluation index (EEI). Ecol. Indic. 3, 27-33.

Orfanidis, S., Panayotidis, P., Ugland, K.I., 2011. Ecological Evaluation Index continuous formula (EEI-c) application: a step forward for functional groups, the formula and reference condition values. Mediterr. Mar. Sci. 12, 199-231.

Palacin, C., Giribet, G., Carner, S., Dantart, L., Turon, X., 1998. Low densities of sea urchins influence the structure of algal assemblages in the western Mediterranean. J. Sea Res. 39, 281-290.

Paoli, C., Morten, A., Bianchi, C.N., Morri, C., Fabiano, M., Vassallo, P., 2016. Capturing ecological complexity: OCI, a novel combination of ecological indices as applied to benthic marine habitats. Ecol. Indic. 66, 86-102.

Parravicini, V., Rovere, A., Vassallo, P., Micheli, F., Montefalcone, M., Morri, C., Paoli, C., Albertelli, G., Fabiano, M., Bianchi, C.N., 2012. Understanding relationships between conflicting human uses and coastal ecosystems status: a geospatial modeling approach. Ecol. Indic. 19, 253-263.

Parravicini, V., Micheli, F., Montefalcone, M., Morri, C., Villa, E., Castellano, M., Povero, P., Bianchi, C.N., 2013. Conserving biodiversity in a human-dominated world: degradation of marine sessile communities within a protected area with conflicting human uses. PLoS ONE 8 (10), e75767.

Peharda, M., Morton, B., 2006. Experimental prey species preferences of Hexaplex trunculus (Gastropoda: Muricidae) and predator-prey interactions with the black mussel Mytilus galloprovincialis (Bivalvia: Mytilidae). Mar. Biol. 148, 1011-1019.

Pérès, J.M., 1982. Major benthic assemblages. In: Kinne, O. (Ed.), Marine Ecology. A Comprehensive, Integrated Treatise on Life in Oceans and Coastal Waters. John Wiley \& Sons publ., Chichester, pp. 119-185.

Personnic, S., Boudouresque, C.F., Astruch, P., Ballesteros, E., Blouet, S., Bellan-Santini, D., Bonhomme, P., Thibault-Botha, D., Feunteun, E., Harmelin-Vivien, M., Pergent, G., Pergent-Martini, C., Pastor, J., Poggiale, J.C., Renaud, F., Thibaut, T., Ruitton, S., 2014 An ecosystem-based approach to assess the status of a Mediterranean ecosystem, the Posidonia oceanica seagrass meadow. PLoS ONE 9 (6), e98994.

Phillips, J.A., Blackshaw, J.K., 2011. Extirpation of Macroalgae (Sargassum spp.) on the subtropical east Australian coast. Conserv. Biol. 25, 913-921.

Piazzi, L., Gennaro, P., Ceccherelli, G., 2015. Suitability of the ALien Biotic IndEX (ALEX) for assessing invasion of macroalgae across different Mediterranean habitats. Mar. Pollut. Bull. 97, 234-240.

Pinedo, S., Jordana, E., Ballesteros, E., 2015. A critical analysis on the response of macroinvertebrate communities along disturbance gradients: description of MEDOCC (MEDiterranean OCCidental) index. PSZN I. Mar. Ecol. 36, 141-154.

Pinedo, S., Jordana, E., Manzanera, M., Ballesteros, E., 2016. Using MEDOCC (MEDiterranean OCCidental) index to evaluate the ecological status of Catalan coastal waters
(Northwestern Mediterranean Sea) over time and depths. In: Munné, et al. (Eds.), Experiences From Ground, Coastal And Transitional Water Quality Monitoring: The EU Water Framework Directive Implementation in the Catalan river Basin District (Part II). Springer International Publishing, Switzerland, pp. 201-226.

Pitacco, V., Orlando-Bonaca, M., Mavrič, B., Popović, A., Lipej, L., 2014. Mollusc fauna associated with the Cystoseira algal associations in the Gulf of Trieste (northern Adriatic Sea). Mediterr. Mar. Sci. 15, 225-238.

Rastorgueff, P.A., Bellan-Santini, D., Bianchi, C.N., Bussotti, S., Chevaldonné, P., Guidetti, P., Harmelin, J.G., Montefalcone, M., Morri, C., Perez, T., Ruitton, S., Vacelet, J., Personnic, S., 2015. An ecosystem-based approach to evaluate the ecological quality of Mediterranean undersea caves. Ecol. Indic. 54, 137-152.

Régis, M.B., 1978. Croissance de deux échinoïdes du golfe de Marseille (Paracentrotus lividus (Lmk) et Arbacia lixula L.). Aspects écologiques de la microstructure du squelette et de l'évolution des indices physiologiques. Thèse Doctorat. Université Aix-Marseille 3, Marseille.

Régis, M.B., 1986. Microstructure adaptative des radioles de Paracentrotus lividus (Echinodermata: Echinoidea) en milieu eutrophisé par des eaux usées. Mar. Biol. (Heidelberg, Ger.) 90, 271-277.

Reker, J., Annunziatellis, A., Mo, G., Tunesi, L., Globevnik, L., Snoj, L., Agnesi, S., Korpinen, S. 2015. Marine Protected Areas in Europe's Seas. An Overview and Perspectives for the Future. European Environment Agency, Publication Office of the European Union, Luxembourg.

Ruitton, S., Francour, P., Boudouresque, C.F., 2000. Relationships between algae, benthic herbivorous invertebrates and fishes in rocky sublittoral communities of a temperate sea (Mediterranean). Estuar. Coast. Shelf S. 50, 217-230.

Ruitton, S., Personnic, S., Ballesteros, E., Bellan-Santini, D., Boudouresque, C.F. Chevaldonné, P., Bianchi, C.N., David, R., Féral, J.P., Guidetti, P., Harmelin, J.G. Montefalcone, M., Morri, C., Pergent, G., Pergent-Martini, C., Sartoretto, S., Tanoue, H., Thibaut, T., Vacelet, J., Verlaque, M., 2014. An ecosystem-based approach to assess the status of the Mediterranean coralligenous habitat. In: Bouafif, C., Langar, H. Ouerghi, A. (Eds.), Proceedings of the 2nd Mediterranean Symposium on the Conservation of Coralligenous and Other Calcareous Bio-concretions, Portorož, Slovenia, 2930 October 2014. RAC/SPA Publ., Tunis, pp. 153-158.

Sala, E., 1997. Fish predators and scavengers of the sea urchin Paracentrotus lividus in protected areas of the north-west Mediterranean Sea. Mar. Biol. 129, 531-539.

Sala, E., Boudouresque, C.F., 1997. The role of fishes in the organization of a Mediterranean sublittoral community. I: algal communities. J. Exp. Mar. Biol. Ecol. 212, 25-44.

Sala, E., Boudouresque, C.F., Harmelin-Vivien, M., 1998. Fishing, trophic cascades, and the structure of algal assemblages: evaluation of an old but untested paradigm. Oikos 425-439.

Sala, E., Kizilkaya, Z., Yildirim, D., Ballesteros, E., 2011. Alien marine fishes deplete algal biomass in the Eastern Mediterranean. PLoS ONE 6 (2), e17356.

Sala, E., Ballesteros, E., Dendrinos, P., Di Franco, A., Ferretti, F., Foley, D., Fraschetti, S. Friedlander, A., Garrabou, J., Güçlüsoy, H., Guidetti, P., Halpern, B.S., Hereu, B. Karamanlidis, A.A., Kizilkaya, Z., Macpherson, E., Mangialajo, L., Mariani, S., Micheli, F., Pais, A., Riser, K., Rosenberg, A.A., Sales, M., Selkoe, K.A., Starr, R., Tomas, F. Zabala, M., 2012. The structure of Mediterranean rocky reef ecosystems across environmental and human gradients, and conservation implications. PLoS ONE 7 (2) e32742.

Sales, M., Cebrian, E., Toas, F., Ballesteros, E., 2011. Pollution impacts and recovery potential in three species of the genus Cystoseira (Fucales, Heterokontophyta). Estuar. Coast. Shelf Sci. 92, 347-357.

Sales, M., Ballesteros, E., Anderson, M.J., Iveša, L., Cardona, E., 2012. Biogeographical patterns of algal communities from the Mediterranean Sea: Cystoseira crinita-dominated assemblages as a case study. J. Biogeogr. 39, 140-152.

Savy, S., 1987. Les predateurs de Paracentrotus lividus (Echinodermata). In: Boudouresque, C.F. (Ed.), Colloque International sur Paracentrotus lividus et les oursins comestibles. GIS Posidonie Publ., Marseille, pp. 413-423.

Schiel, D.R., 2011. Biogeographic patterns and long-term changes on New Zealand coasta reefs: non-trophic cascades from diffuse and local impacts. J. Exp. Mar. Biol. Ecol. 400 33-51.

Schiel, D.R., Foster, M.S., 2006. The population biology of large brown seaweeds: ecological consequences of multiphase life histories in dynamic coastal environments. Annu. Rev. Ecol. Syst. 37, 343-372.

Sfriso, A., Facca, C., Ghetti, P.F., 2009. Validation of the Macrophyte Quality Index (MaQI) set up to assess the ecological status of Italian marine transitional environments. Hydrobiologia 617, 117-141.

Steneck, R.S., Graham, M.H., Bourque, B.J., Corbett, D., Erlandson, J.M., Estes, J.A., Tegner, M.J., 2002. Kelp forest ecosystems: biodiversity, stability, resilience and future. Environ. Conserv. 29, 436-459.

Thibault, J.C., Bretagnolle, V., Dominici, J.M., 2001. Le balbuzard pêcheur en Corse. Piazzola A. Pub., Ajaccio, p. 184.

Thibaut, T., Blanfuné, A., 2014. Préfiguration du réseau macroalgues - Bassin Rhône Méditerranée Corse - Application de la directive Cadre Eau - Rapport d'état écologique des masses d'eau - Littoral rocheux méditerranéen français - Réévaluation de 12 masses d'eau. :p. 36 e-publication: http://www.medtrix.fr/index.php/view/ (Accessed on February 23, 2016).

Thibaut, T., Markovic, L., 2009. Préfiguration du réseau macroalgues - Bassin Rhône Méditerranée Corse - Application de la Directive Cadre Eau - 2000/60/CE - Masses d'eau littorales de la côte continentale française - Rapport d'état écologique des masses d'eau. Ensemble du Littoral rocheux continental français de Méditerranée. p. 31 e-publication: http://www.medtrix.fr/index.php/view/ (Accessed on February 23, 2016).

Thibaut, T., Pinedo, S., Torras, X., Ballesteros, E., 2005. Long-term decline of the populations of Fucales (Cystoseira, Sargassum) in the Albères coast (northwestern Mediterranean). Mar. Pollut. Bull. 50, 1472-1489. 
Thibaut, T., Mannoni, P.A., Markovic, L., Geoffroy, K., Cottalorda, J.M., 2008. Préfiguration du réseau macroalgues - Bassin Rhône Méditerranée Corse - Application de la Directive Cadre Eau - 2000/60/CE - Mission mai - juin 2007- Rapport d'état écologique des masses d'eau. :p. 19 e-publication: http://www.medtrix.fr/index.php/view/ (Accessed on February 23, 2016).

Thibaut, T., Markovic, L., Blanfuné, A., 2010. Préfiguration du réseau macraolgues - Bassin Rhône Méditerranée Corse - Application de la directive Cadre Eau - Rapport d'état écologique des masses d'eau. Littoral rocheux de la Corse. :p. 24 e-publication: http://www.medtrix.fr/index.php/view/ (Accessed on February 23, 2016).

Thibaut, T., Markovic, L., Blanfuné, A., 2011. Préfiguration du réseau macroalgues - Bassin Rhône Méditerranée Corse - Application de la directive Cadre Eau - Rapport d'état écologique des masses d'eau. Littoral rocheux de la Corse. p. 22 e-publication: http://www.medtrix.fr/index.php/view/ (Accessed on February 23, 2016).

Thibaut, T., Blanfuné, A., Boudouresque, C.F., Verlaque, M., 2015. Decline and local extinction of Fucales in the French Riviera: the harbinger of future extinctions? Mediterr. Mar. Sci. 16, 206-224.

Thibaut, T., Blanfuné, A., Boudouresque, C.F., Cottalorda, J.M., Hereu, B., Susini, M.L. Verlaque, M., 2016. Unexpected temporal stability of Cystoseira and Sargassum forests in Port-Cros, one of the oldest Mediterranean marine National Parks. Cryptogam. Algol. 37, 1-30.

Thiriet, P., 2014. Comparaison de la structure des peuplements de poissons et des processus écologiques sous-jacents, entre les forêts de cystoseires et des habitats structurellement moins complexes, dans l'infralittoral rocheux de Méditerranée nord-occidentale. Doctoral Thesis. University of Nice Sophia-Antipolis, Nice.

Vacchi, M., Montefalcone, M., Parravicini, V., Rovere, A., Vassallo, P., Ferrari, M., Morri, C., Bianchi, C.N., 2014. Spatial models to support the management of coastal marine ecosystems: a short review of best practices in Liguria, Italy. Mediterr. Mar. Sci. 15, 189-197.

Velimirov, B., 1984. DOC in the water column above Posidonia meadows. In: Boudouresque, C.F., Jeudy De Grissac, A., Olivier, J. (Eds.), First International Workshop on Posidonia oceanica beds. GIS Posidonie Publ., Marseille, pp. $179-184$

Verlaque, M., 1987. Relations entre Paracentrotus lividus (Lamarck) et le phytobenthos de Méditerranée occidentale. In: Boudouresque, C.F. (Ed.), Colloque international sur Paracentrotus lividus et les oursins comestibles. GIS Posidonie Publ., Marseille, pp. 5-36.
Verlaque, M., Nédelec, H., 1983. Biologie de Paracentrotus lividus (Lamarck) sur substrat rocheux en Corse (Méditerranée, France): alimentation des adultes. Vie et Milieu 33, 191-201

Vergés, A., Alcoverro, T., Ballesteros, E., 2009. Role of fish herbivory in structuring the vertical distribution of canopy algae Cystoseira spp. in the Mediterranean Sea. Mar. Ecol. Prog. Ser. 375, 1-11.

Vergés, A., Steinberg, P.D., Hay, M.E., Poore, A.G.B., Campbell, A.H., Ballesteros, E., Heck Jr., K.L., Booth, D.J., Coleman, M.A., Feary, D.A., Figueira, W., Langlois, T., Marzinelli, E.M., Mizerek, T., Mumby, P.J., Nakamura, Y., Roughan, M., van Sebille, E., Gupta, A.S., Smale, D.A., Tomas, F., Wernberg, T., Wilson, S.K., 2014. The tropicalization of the temperate marine ecosystems: climate-mediated changes in herbivory and community phase shifts. Proc. R. Soc. B 281 (1789) (20140846).

Vergés, A., Doropoulos, C., Malcolm, H.A., Skye, M., Garcia-Pizá, M., Marzinelli, E.M., Campbell, A.H., Ballesteros, E., Hoey, A.S., Vila-Concejo, A., Bozec, Y.M., Steinberg, P.D., 2016. Long-term empirical evidence of ocean warming leading to tropicalization of fish communities, increased herbivory, and loss of kelp. Proc. Natl. Acad. Sci. 113 (48), 13,791-13,796.

Wells, E., Wilkinson, M., Wood, P., Scanlan, C., 2007. The use of macroalgal species richness and composition on intertidal rocky seashores in the assessment of ecological quality under the European Water Framework Directive. Mar. Pollut. Bull. 55, $151-161$.

West, B. De Burgh, M. Jeal, F, 1977. Dissolved organics in the nutrition of benthic invertebrates. In: Keegan, B.F., Céidigh, P.O., Boaden, P.J.S. (Eds.), Biology of Benthic Organisms. Pergamon Press, Oxford, pp. 587-593.

White, J., Irvine, K., 2003. The use of littoral mesohabitats and their macroinvertebrates in the assemblages of lakes. Aquat. Conserv. 13, 331-351.

Witman, J.D., 1987. Subtidal coexistence: storms, grazing, mutualism, and the zonation of kelps and mussels. Ecol. Monogr. 57, 167-187.

Witman, J.D., Dayton, P.K., 2001. Rocky subtidal communities. In: Bertness, M.D., Gaines, S.D., Hay, M. (Eds.), Marine Community Ecology. Sinauer Press, Sunderland, Massachussetts, pp. 339-366.

Worm, B., Lotze, H.K., 2006. Effects of eutrophication, grazing, and algal blooms on rocky shores. Limnol. Oceanogr. 51, 569-579. 